\title{
The Peasant's Bonds to Gaul, God, Land and Nature: The Myth of the Rural and Jules Breton's Le Chant de l'alouette
}

\section{Maureen Ryan}

Volume 19, numéro 1-2, 1992

Art as Propaganda

Art et propagande

URI : https://id.erudit.org/iderudit/1072854ar

DOI : https://doi.org/10.7202/1072854ar

Aller au sommaire du numéro

\section{Éditeur(s)}

UAAC-AAUC (University Art Association of Canada | Association d'art des universités du Canada)

\section{ISSN}

0315-9906 (imprimé)

1918-4778 (numérique)

Découvrir la revue

Citer cet article

Ryan, M. (1992). The Peasant's Bonds to Gaul, God, Land and Nature: The Myth of the Rural and Jules Breton's Le Chant de l'alouette. RACAR : Revue d'art canadienne / Canadian Art Review, 19(1-2), 79-96.

https://doi.org/10.7202/1072854ar

\section{Résumé de l'article}

Le Chant de l'alouette, représentant une jeune paysanne dans les champs, à l'aube, fait l'objet d'une histoire remarquable depuis sa première apparition au Salon de 1885. Peinte en 1884 par Jules Breton, peintre renommé de la vie rurale française, l'oeuvre fut achetée par un entrepreneur de Chicago, Henry Field, peu de temps après avoir été montrée au public français. Exposé par la suite à l'Exposition universelle de Columbia en 1893, le tableau fut acquis par l'Art Institute de Chicago en 1917. Dans le contexte américain, ce tableau de Breton fut l'objet d'un engouement populaire inhabituel et fournit à Willa Cather le titre de son roman bien connu de 1915, The Song of the Lark. Il fut aussi choisi comme l'oeuvre d'art la plus populaire aux États-Unis lors d'un sondage effectué par un journal de Chicago en 1934. De récentes analyses historiques à caractère révisionniste, vouées à la réévaluation d'artistes français marginalisés par le canon avant-gardiste du modernisme, ont eu tendance à célébrer le choix par Breton d'un sujet à caractère national et ont insisté sur les racines paysannes de l'artiste et sur le fait qu'il avait maintes fois déclaré sa « sympathie " pour la vie rurale. La présente étude propose cependant une lecture différente de l'oeuvre de Breton en évaluant les moyens par lesquels une telle représentation académique du paysan pouvait véhiculer des notions essentiellement conservatrices de la vie rurale. Les interprétations du Chant de l'alouette offertes par les critiques du Salon de 1885 sont utilisées comme porte d'entrée pour cette analyse. Ce que ce discours critique souligne, c'est que les spectateurs de 1885 étaient encouragés à lire l'image de Breton selon les termes d'un ensemble de stéréotypes qui définissait le paysan sous la forme d'un " autre " sur le plan intellectuel et « racial " par rapport au citadin moderne.

Représentée en termes de liens à la terre et aux saisons, à la tradition religieuse et au passé primitif de la Gaule, la représentation de la jeune moissonneuse à l'aube servait à affirmer une construction mythique particulière de la vie rurale persistant toujours dans le " présent moderne » des années 1880. Dans l'arène publique des Salon des débuts de la Troisième République, le Chant de l'alouette réaffirmait ainsi la tradition et le passé sur plusieurs plans. Alors que les associations narratives et le mode stylistique du tableau constituaient une réplique aux stratégies « dé-familiarisantes » de l'avant-garde impressionniste qui lui était contemporaine, la représentation de la paysanne et sa faucille offrait aussi une forme de défi visuel aux représentations du paysan qui étaient alors mises de l'avant, durant les années 1880 , par le nouveau gouvernement républicain qui cherchait à apporter des réformes et à moderniser les campagnes.
Tous droits réservés @ C UAAC-AAUC (University Art Association of Canada | Association d'art des universités du Canada), 1994
Ce document est protégé par la loi sur le droit d'auteur. L’utilisation des services d’Érudit (y compris la reproduction) est assujettie à sa politique d'utilisation que vous pouvez consulter en ligne.

https://apropos.erudit.org/fr/usagers/politique-dutilisation/ 


\title{
The Peasant's Bonds to Gaul, God, Land and Nature: The Myth of the Rural and Jules Breton's Le Chant de l'alouette*
}

\author{
Maureen Ryan, University of British Columbia
}

Résumé

e Chant de l'alouette, représentant une jeune paysanne dans les champs, à l'aube, fait l'objet d'une histoire remarquable depuis sa première apparition au Salon de 1885. Peinte en 1884 par Jules Breton, peintre renommé de la vie rurale française, l'oeuvre fut achetée par un entrepreneur de Chicago, Henry Field, peu de temps après avoir été montrée au public français. Exposé par la suite à l'Exposition universelle de Columbia en 1893, le tableau fut acquis par l'Art Institute de Chicago en 1917. Dans le contexte américain, ce tableau de Breton fut l'objet d'un engouement populaire inhabituel et fournit à Willa Cather le titre de son roman bien connu de 1915 , The Song of the Lork. II fut aussi choisi comme l'oeuvre d'art la plus populaire aux États-Unis lors d'un sondage effectué par un journal de Chicago en 1934. De récentes analyses historiques à caractère révisionniste, vouées à la réévaluation d'artistes français marginalisés par le canon avant-gardiste du modemisme, ont eu tendance à célébrer le choix par Breton d'un sujet à caractère national et ont insisté sur les racines paysannes de l'artiste et sur le fait qu'il avait maintes fois déclaré sa "sympathie" pour la vie rurale. La présente étude propose cependant une lecture différente de l'oeuvre de Breton en évaluant les moyens par lesquels une telle représentation académique du paysan pouvait véhiculer des notions essentiellement conservatrices de la vie rurale. Les interprétations du Chant de l'alouette offertes par les critiques du Salon de 1885 sont utilisées comme porte d'entrée pour cette analyse. Ce que ce discours critique souligne, c'est que les spectateurs de 1885 étaient encouragés à lire l'image de Breton selon les termes d'un ensemble de stéréotypes qui définissait le paysan sous la forme d'un "autre" sur le plan intellectuel et "racial" par rapport au citadin moderne.

Représentée en termes de liens à la terre et aux saisons, à la tradition religieuse et au passé primitif de la Gaule, la représentation de la jeune moissonneuse à l'aube servait à affirmer une construction mythique particulière de la vie rurale persistant toujours dans le "présent modeme" des années 1880. Dans l'arène publique des Salon des débuts de la Troisième République, le Chont de l'alouette réaffirmait ainsi la tradition et le passé sur plusieurs plans. Alors que les associations narratives et le mode stylistique du tableau constituaient une réplique aux stratégies "dé-familiarisantes" de l'avant-garde impressionniste qui lui était contemporaine, la représentation de la paysanne et sa faucille offrait aussi une forme de défi visuel aux représentations du paysan qui étaient alors mises de l'avant, durant les années 1880, par le nouveau gouvernement républicain qui cherchait à apporter des réformes et à moderniser les campagnes.
$\mathrm{R}$ ural culture in France changed rapidly over the course of the nineteenth century. This phenomenon, which has been the subject of much recent study, was recognized and documented during the period itself. From the mid-nineteenth century on, historical and economic surveys of the peasantry pointed to land reform and industrialization as factors contributing to the depopulation of the countryside; these accounts also argued that new technologies and increased contact with modern urban forms were irrevocably altering age-old patterns of rural life and labour. ${ }^{1}$ Over the last two-and-a-half decades art historians have investigated the relationship between the portrayal of the peasant in French art in the nineteenth century and this period of rapid change. In particular, Robert $\mathrm{L}$. Herbert, Linda Nochlin, T.J. Clark, Griselda Pollock and Fred Orton, and Neil McWilliam and Christopher Parsons, have addressed the role played by the visual arts in promoting the pervasive nineteenth-century myth in which the countryside was insistently structured as a static and unchanging realm, one that provided a stable-seeming alternative to the ongoing transformations of the modern urban sphere. ${ }^{2}$ Paintings that invoked this myth occupied an important place in the official Salons that displayed French art in the second half of the century. Repeatedly picturing rural life through reference to its traditional forms, such imagery relied upon the exclusion of any signs of change and modernity-the intrusion of the industrial age, new methods of production, or shifts in cultural moeurs, that could suggest the inroads of a new economic order. ${ }^{3}$

Jules Breton's Le Chant de l'alouette (Fig. 1), painted in 1884 and exhibited in the Salon of 1885 , offers a ready example of the way in which the image of the peasant could function as a visual foil to the changing forms of modern urban life. Executed in the academic harmonies that overtly refused any inroads of contemporary naturalism or impressionism, Le Chant de l'alouette takes as its focus a young peasant woman in the fields at dawn. Shoeless, wearing the simple dress of a field worker and furnished with a sickle, the peasant is represented as halting in mid-step, her attention caugh - - so the title informs the viewer-by the morning song of the skylark. ${ }^{4}$ Produced by a well-established member of the Institute who had been exhibiting and marketing scenes of peasant life for some twenty-five years, ${ }^{5}$ Breton's painting presented the Salon public with much that was familiar in terms of peasant genre in nineteenth-century France. The image referred to-but did not depict ex- 
Figure 1. Jules Breton, Le Chant de l'alouette, The Song of the Lark, 1884. Oil on canvas, $110.6 \times 85.8 \mathrm{~cm}$. Henry Field Memorial Collection (Photograph COI993 The Art Institute of Chicago. All rights reserved).

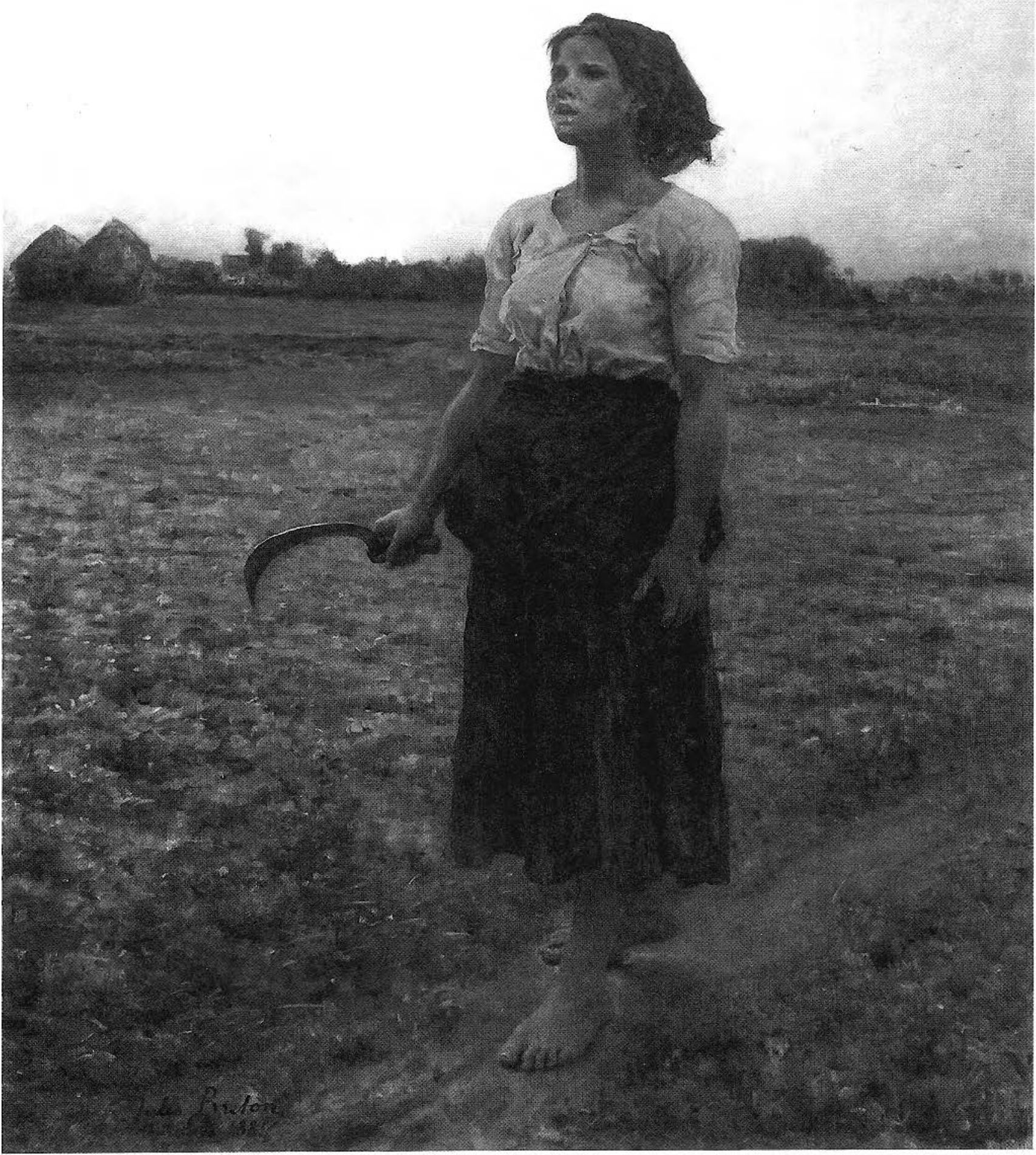


plicitly-a form of labour that could be linked to centuries-old harvesting practices. And, like numerous other paintings of the peasant that had been exhibited in the Salons since the 1850s, the abstract entity of France's "le paysan" was conjured up in the person of the peasant woman: youthful, robust and easily eroticized by her location in a nature that was safely distanced from the sphere of problematic class identifications of the city. ${ }^{6}$

Yet despite the traditional vocabulary of both its subject and style, Le Chant de l'alouette did lay claim to a kind of contemporaneity within the public arena of the Salon of 1885. As a genre image taking up a purportedly modern French subject, the painting could imply a representation of the everyday that suggested that this peasant with sickle and homespun clothes embodied a still existent aspect of contemporary France. It is here that the painting raises a specific set of issues which are the subject of this paper. These turn on the way in which an academic image like Breton's worked to naturalize its representation of the social, in order to propose an authoritative portrayal of the countryside-one that clearly distanced itself from the defamiliarizing strategies of recent avant-garde practice where the literary and narrative references of traditional Salon art had been so overtly rejected.

Construction of the painting's meaning by critics in the numerous reviews that responded to the annual exhibition of French art in the Paris Salon provides a point of access for this assessment. What this critical discourse underscores is the way in which Le Chant de l'alouette enabled at least one set of viewers to engage in a number of related and mutually reinforcing readings, a set of narrative constructs that served to assert the painting's interest as a genre image. These manipulated a body of stereotypes that worked to mediate social relations and to objectify for a predominantly urban and bourgeois public a peasantry that comprised about one-half of the nation's population and that was differentiated by region, as well as by its relation to property, labour and to the institutions of religion and the state. Ordered in terms of difference in relation to the urban dweller, and set in play by Le Chant de l'alouette, such stereotypes could assert the persistence into the present of the Third Republic, of a particular mythic construct of the rural, one that aligned itself with the authority of tradition by defining the peasantry as locked in a timeless stasis outside modern history.

The Critical Reception

When Le Chant de l'alouette was exhibited in the Salon, most accounts of the painting by art critics were limited to a description of the pose of the young female harvester and to the hour of day. ${ }^{7}$ A few reviewers, however, extended these terms of references. André Michel, for example, writing in the conservative Gazette des beaux-arts, admired the landscape and what he termed a quasi-religious quality in the painting. But Michel also engaged in a critique of the work that called up the terms in which the peasant functioned as a kind of primitive "other" in relation to the urban citadin:

Le paysage . . . est superbe, la solennité douce et presque réligcuse de l'heure est admirablement sentie et exprimée. La jeune paysanne qui s'avance ... est aussi fort belle. Oserai-je dire qu' elle est trop belle ou que, du moins, elle a trop l'air de se douter de la splendeur du spectacle que la nature donne tous les matins aux paysans et aux alouettes? On dirait qu'elle veut nous la signaller et que, en allant à son travail, elle pense surtout à nous qui la regardons. Le Paysan peut-être beau assurément, mais il ne s'en doute pas. Sa beauté lui vient de choses qu'il ignore, de ce ciel qui s'étend sur sa tête et mûrit ses moissons, de cette terre qu'il féconde par ses labeurs, de cette nature qui l'enveloppe sans qu'il leur ait jamais demandé leur sécret. ${ }^{8}$

In Michel's formulation, an actual young harvester is presumed to be so much a part of the natural world that she would be unable to engage in its contemplation as aestheticized spectacle. She should properly be rendered as a result, like the landscape in which she is situated, as the unconscious object of the urban gaze. While other commentaries were less critical of the painting itself, the peasant's identity with nature was a recurrent theme that marked out the ways in which difference could be inscribed in such representations. Henri Chantavoine's review in the conservative La Nouvelle revue, for example, made an equation between the harvester and the lark:

une fille des champs . . lève les yeux en haut et, comme l'alouette, envoie son aubade au soleil. Cela pourrait s'appeler la première chanson, chanson et salut, que la fillette et l'alouette, ces deux paysannes, adressent d'un cocur joyeux et reconnaissant à la lumière. L'innocence ct la paix de la vie rustique, le contentement des existences simples et la joie de la nature maternelle souriant à ce bonheur paisible, sont délicieusement éxprimé. . .?

Théodore Véron, whose privately published review was available as an assessment of the Salon, also suggested that the peasant responded like the lark to the spectacle of both the dawn and the alma parens of nature and the earth. Yet Véron also called the peasant "une Gauloise triomphante."10 This evocation of ancient Gaul was not an isolated one. 
The critic for the conservative art periodical L'Artiste, Charles Ponsonaille, observed:

L'alerte paysanne dont la farigue du jour n'a point alourdi le pas, écoure le chant joyeux de l'oiseau des Gaules et son âme vibre à l'unisson. Sur ses lèvres vient un refrain d'autrefois; quelque vielle chanson bretonne parlant de bergère et de fils de roi et peut-être aussi des Saintes nimbées de là-haut. ${ }^{11}$

Writing in Le Dix-neuvième siècle, Henry Fouquier similarly commented on the Gaulish associations of the lark:

L'Alouette . . . est un tableau à une seule figure, une jeune fille qui va au travail, à la première heure, et regarde l'alouetre Gauloise, dont la chanson aigüe semble descendre du ciel. Alouettes toutes les deux, l'oiseau et la jeune fille, trouvent dans la nature une instinctive joie également insouciantes ct libres. ${ }^{12}$

The critic for La Presse, J. Noulens, more specifically linked the youthful peasant woman to the religious practices of the nation's early inhabitants: "malgré ses vêtements grossiers, ses traits et ses attaches vulgaires, elle a un caractère mystique de prêtresse celtique dans un bois sacré." Noulens altered this reading slightly in another review, noting that, "Son air inspiré et la faucille qu'elle tient à la main lui donnent le caractère mystique d'une druidesse dans un bois sacré." 13

The facility with which these critics could equate the peasant in Le Chant de l'alouette with a Gaulish past, with religion and with nature points to the way in which such a genre image could be understood to encourage a textual and associative reading. Yet, these identifications also drew significance and power from their reference to a set of definitions and stereotypes that located the peasant-and peasant women-outside of modern culture and bound by immutable ties to nature, the land and the past.

\section{The Gaulish/Celtic Heritage}

That the modern peasant could be traced to the early Gaulish and Celtic tribes of France was an important aspect in the construction of the peasant as a primitive "other" in relation to France's urban population. In the sixteenth century the Gauls and Celts were "discovered" and posed as the ancestors of the French nation. As Claude-Gilbert Dubois has argued, the emergence at this time of what amounted to a new interest in the pagan past of pre-Roman Gaul had an ideological function. The new ancestry functioned to free France from a total dependence on the Graeco-Roman cultural legacy which implied that France's institutions, arts and religion were derived from a heritage rooted in a rival nation, that of sixteenth-century Renaissance Italy. ${ }^{14}$ By the nineteenth century, the Gaulois-the broad term which came to be used to encompass both Gauls and Celts ${ }^{15}$ - were accorded symbolic status as the earliest ancestors of modern France. Yet, within this general categorization there were more specific divisions. One tradition current during the Bourbon Restoration of the early nineteenth century argued that the Gauls provided the ancestral stock for France's Third Estate, comprised of both le peuple and la bourgeoisie. In contrast, the subsequent Germanic invaders of the sixth century A.D.- the Frankswere viewed as forebears of the ruling nobles and monarchs of the nation. ${ }^{16}$ Using this model, liberal historians were able to argue that a racial conflict between the two groups, and the enforced submission of Gaulois to Franks, provided the historic source for modern conflicts that had resulted in contemporary challenges to aristocratic and royal authority. By the middle of the nineteenth century, however, as the middle classes gained increasing power, it was the peasantry alone rather than the Third Estate in general who were viewed as the descendants of the nation's early inhabitants. Thus, in the early years of the Second Empire, when new political exigencies and changing forms of urban experience stimulated a study of peasant folklore, economics and moeurs, ${ }^{17}$ analyses of rural culture such as Dareste de la Chavanne's Histoire des classes agricoles en France of 1854, Bonnemère's Histoire des paysans of 1856 , or Leymarie's Histoire des paysans en France, published in the same year, placed the Gauls and their relationship to the land as the starting point determining the subsequent status of the peasant through the centuries. ${ }^{18}$

With rural history viewed as rooted in France's preRoman past, categorization of the peasant in terms of a "race" apart, and as contemporary representatives of "nos races gauloises," was frequent in the nineteenth century. ${ }^{19}$ Such formulations were supported by nineteenth century archaeological and historical study which emphasized that ties to Gaulish and Celtic traditions could be traced to the modern rural population. Henri Martin, for example, in his Histoire de France, first published in 1833, had argued that the Druidic deities of the ancient Gauls had not been eradicated by the advent of Christianity in France. ${ }^{20}$ By 1896 Alexandre Bertrand, in Nos origines: la religion des Gaulois: Les Druides et la Druidisme, had gone farther, advocating the study of the contemporary French peasant as a means by which the ancient Gaulish traditions and legends could be illuminated. Speaking of France's early inhabitants he wrote: 
Il nous paraît probable que les descendants de ces tribus pastorales et agricoles [the Gauls and Celts] forment encore le fond principal de nos populations rurales de l'Ouest er du centre de la France. Nous croyons pouvoir retrouver chez elles, nous devons au moins y rechercher, l'écho, quelque affaibli qu'il soit, de leur esprit, de leurs superstitions, de leur légendes. ${ }^{21}$

Popular literature and folkloric studies had given a currency to such theories ever since mid-century. As one example, George Sand's 1844 novel Jeanne, a work stimulated by the author's study of rural life in the French province of the Centre, took form around the Gaulish/Celtic heritage ascribed to the modern peasant. The final denouement of the story hinged on the conflict which emerged from the meeting of the resultant "primitive" peasant culture with modern society of the nineteenth century. Ultimately destroyed through her contact with contemporary manners and morals, the novel's peasant heroine, Jeanne, is described by Sand as an "Isis gauloise" and compared to a "fille des druides" suddenly transported from the past into the present. ${ }^{22}$ The young peasant's habits, beliefs and her socalled "mystic" relationship to nature are made to stand as signs that "le pur sang de la race gauloise primitive s'est conservé jusqu'à nos jours sans mélange dans quelques tribus rustiques de nos provinces centrales." ${ }^{23}$ Reinforcing this characterization is the rural environment in which the novel is set. The province of the Centre is conjured up as "une terre primitive qui porte les stigmates mystérieux de notre plus antique civilisation," and as a region where "l'homme semble avoir conservé son type gaulois et ses croyances fantastiques...."24

\section{The Peasant and Religion: Pagan and Christian Tradition}

Ironically, such assertions that Gaulish/Celtic practices persisted in the countryside were not viewed as threatening the hegemony of the Catholic Church in rural France. ${ }^{25}$ Nineteenth-century accounts repeatedly described the Gauls and Celts as a religious "race." 26 Indeed, this spiritual proclivity ascribed to the nation's early inhabitants was posed as having paved the way for the advent of Christianity in France. For an historian like Henri Martin writing in the first half of the century, the essential premise of Gaulish and Celtic religion, a belief in the immortality of the human soul, effectively linked Druidism to the same IndoEuropean sources that were viewed as having spawned the major religions of Western civilization. This common origin, he argued, prepared the way for the acceptance of Christianity in pagan Gaul. ${ }^{27}$ The conservative Ernest Renan also viewed the religious and metaphysical aspects of Druidism as being in harmony with Christianity. In an article of 1854 , "La Poesie des races celtiques," this affinity between the two religions was assessed in relation to the Celtic ancestors of the peasant in France's western-most province of Bretagne. Renan argued that, unlike the situation of pagan Germanic tribes who fought off Christianity, physical isolation and closeness to nature had nurtured the spiritual character of the Druidic Celts, enabling Christianity to find a fertile territory: "Cette douce petite race était naturellement chrétienne. Loin de les altérer et de leur enlever quelquesunes de leurs qualités, le christianisme les achevait et les perfectionnait." ${ }^{28}$ Arguments such as Renan's contributed to the mystic character attributed in the nineteenth century to the modern peasant of Brittany. This character, as Catherine Bertho has shown, owed as much to the perceived Celtic ancestry ascribed to the Breton, an ancestry seen to be registered in the physical signs of former Druidic worship such as the standing stones or dolmens which marked Brittany's rural landscape, as it did to the traditional categorization of the region as the most Catholic of France's provinces. ${ }^{29}$ Significantly, interest in the influence of Druidic practice or of Gaulish and Celtic legends on the present was not limited to this one region of the nation. The new field of folklore studies which emerged in the nineteenth century supplemented historical and archaeological investigations, such as those of Martin and Bertrand, and gave popular currency to the idea that rural harvest festivals, religious fêtes, and local superstitions throughout rural France as a whole had merged Gaulish/Celtic traditions with Christianity. ${ }^{30}$ In turn novels on rural life, travel accounts, illustrated magazines and Salon paintings reinforced this notion and derived much of their exotic and picturesque character from the needs of an urban public bent on seeking the primitive, the foreign and the past within the nation's own boundaries. ${ }^{31}$

Concern with these origins of the nation's modern peasant had one important effect. Circumvented by such constituting of a mystic and spiritual antecedent to modern religious practice were the divisive contemporary debates concerning the status of institutionalized Catholicism in the modern countryside. Through the nineteenth century religious and monarchical conservatives viewed the peasant's bonds to the church and tradition as a bulwark upholding stability in a social structure which was seen to be under threat in the decades following the overthrow of the ancien régime by the French Revolution. ${ }^{32}$ Republicans, however, who formed France's liberal opposition through three-quarters of the century, saw the hold of Catholicism in the countryside as impeding democratic reform and progress. The 
power of a local curé to instil a conservative ideology which demanded allegiance to the authority of monarch, pope and God, and by extension to a hierarchical social structure which supported these institutions, threatened the declared Republican ideals of liberté, égalité and fraternité. Set in place following the Republican accession to power in 1879, the policies that attempted to curtail religious influence in the countryside responded to this situation and became one of the major foci for debates on the status of the peasant through the 1880 s. $^{33}$

\section{Bonds to Land and Nature}

Identifications linking the peasant with both the earth and nature were an important component in the stereotyping of peasant culture as static and unchanging. Throughout France, the nature and conditions of peasant land tenure varied regionally, and within the peasantry as a class. The peasant as owner, tenant or hired day labourer entailed a varying set of economic, legal and social relationships. ${ }^{34}$ Yet repeatedly through the nineteenth century, the peasant's relations to the land and to nature as a whole were defined in metaphorical terms that served to obscure the specifics of a rural economy, instead implying a set of bonds that were essential and immutable.

Characterization of the peasant in terms of an instinctive "love" for the soil was one such convention that was reworked endlessly in the nineteenth century. The metaphor romanticized the diurnal and seasonal patterns of rural labour and marked out the peasant's separation from the wage labour contracts of the urban worker. ${ }^{35}$ Frequent claims that the peasant shared an identity with the earth functioned in similar ways. At mid-century, for example, the historian Leymarie described the peasant as belonging to the earth, "presqu'au même titre que les arbres et ruisseaux." 36 In one variant, as in Michelet's famous passage in Le Peuple of 1846, the concept of such identity gave a formative role to the land:

Homme de la terre et vivant tout en elle, il semble fait à son image. Comme elle, il est avide; la terre ne dit jamais: "Assez." Il est obstiné autant qu'elle est ferme et persistante; il est patient à son exemple, et non moins qu'elle indestructible; tour passe, et lui, il reste. ${ }^{37}$

Deterministic theories of milieu prevalent in the nineteenth century legitimized such assessments, ${ }^{38}$ validating as well the frequent analyses of the peasant's character as formed by the whole of the natural environment. Michelet, again in Le Peuple, argued that the peasant was introspective and meditative as the result of being isolated constantly in nature. ${ }^{39}$ Renan, in his 1854 article on Celtic literature, cited the climate and geography of Brittany as formative factors in an alleged tendency of the Breton peasant towards melancholy and resignation. ${ }^{40}$ Views of the peasant as savage or animalistic also responded to these concepts. Thus in Balzac's Les Paysans of 1846 and Zola's La Terre of 1887, women and men within the peasantry are portrayed as brutal because of a perennial contact with forces of nature that demand a bitter struggle for survival.

One ramification of these arguments was that such bonds to nature were viewed as precluding any capacity on the part of the peasant for intellectual reflection. George Sand raised this issue when she addressed the effects of the peasant's constant labour on the land in 1844 :

Qui peut nous révéler le mode d'existence de ces âmes si peu developpées?. A quoi pense le labourer qui creuse patiemment son sillon monotone? A quoi pense le boeuf qui rumine couché dans l'herbe et la cavale étonnée qui vous examine par-dessus le buisson? Est-ce donc la même vie qui circule lentement dans les veines de l'homme et dans celle de l'animal attaché au travail de la terre? ${ }^{41}$

Sand's question, which was posed as the philosophical frame to her novel of rural life, Jeanne, was not an isolated one. ${ }^{42}$ Indeed, much like the art critic André Michel's analysis of Breton's Le Chant de l'alouette which was quoted at the outset of this study, the query presumed an inability on the part of the peasant to engage in disinterested aesthetic contemplation. Sand herself, in La Mare au diable of 1846, had been explicit in insisting that the peasant could perceive aesthetic pleasure in brief, though possibly unsustainable moments: "Dieu me préserve de croire qu'ils ne soient pas supérieurs aux animaux qu'ils dominent et qui'ils n'aient pas par instants une sorte de révélation extatique qui charme leur fatigue et endort leurs soucis." 43 Extending this analysis, she contrasted her own admiration of the beauty and peace of rural settings with that of the peasant and cited Virgil to illustrate the long tradition in European culture that viewed those who laboured in the countryside as too enmeshed in nature to appreciate their environment.

De son coté, l'homme de travail est trop accablé, trop malheurcux, et trop effrayé de l'avenir pour jouir de la beauté des campagnes et des charmes de la vie rustique ....

Le mot triste et doux de Virgile: "O heuruex l'homme des champs s'il connaissait son bonheur!" est un regret: mais, ... c'est aussi une prediction. Un jour viendra où le laboureur pourra être aussi un artiste, sinon pour exprimer . . du moins pour sentir le beau. 44 
This latter point was made frequently in the nineteenth century. Eugène Bonnemère in his Histoire des paysans registered a similar observation, ${ }^{45}$ as did novelist and art critic Ernest Chesneau in 1880:

\begin{abstract}
Il demeure ployée sous la tyrannie de la glèbe et du labeur qu'il exige. L'excès de la peine physique a étouffé en lui tout développement intellectuel. Il semble nous dire que le travail des bras est exclusif non des fonctions de l'âme, mais des fonctions du cerveau. Il peut prier, penser non .... Il devient une force: hélas, une force aveugle. Car il n'a même pas la jouissance de la nature et ses beautés. S'il regarde l'horizon c'est pour juger le temps du lendemain. L'harmonie des couleurs, la finesse des tons, la grace des contours, la majesté des lignes échappent à sa connaissance. ${ }^{46}$
\end{abstract}

Even the Republican journalist and art critic, Louis de Fourcaud, would analyse the peasant in these same terms in the liberal journal Le Gaulois in May 1882:

On lui prête de grandes reveries tranquilles; il a surtout de grands placidités lorsque ses intérêts ne sont en jeu ... Il n'est pas contemplatif d'ordinaire: la beauté d'un site est sur lui de nul effet. Un bel arbre n'est pour lui qu'un bon fournisseur de fagots ou de fruits, non pas un riche ornament de la campagne. ${ }^{47}$

This repeated image of environment overwhelming human capacity produced across a range of political spectrums was reasserted by the gendered content of these discourses. Nineteenth-century constructs that juxtaposed masculine transformative agency with a passive and biologized femininity ${ }^{48}$ had particular implications in terms of stereotypes of the peasant. For example, Michelet's well known evocation in Le Peuple of the male peasant as the lover of an earth that is made fertile by his labours, or the historian Bonnemère's image of the peasant inseminating the land and waiting nine months for his harvest, ${ }^{49}$ effectively reworked familiar western constructs of a masculine generative power perceived to transcend class or cultural affiliation. As L'Intermédiare des chercheurs et curieux of 1885 pointed out for its readership, sexualized metaphors which categorized the earth as a woman, or which evoked the plough as a phallus and ploughing itself as sexual intercourse, could be found in texts that ranged from Greek and Roman times, through the Renaissance and into the modern era. ${ }^{50}$ Yet, in reference to the male peasant in the nineteenth century, such masculinized agency did not preclude the stereotypical bonds perceived to tie the peasantry as a whole to nature and the environment. Thus, in both Michelet and Bonnemère, it is an unreasoning passion which determines the male peasant's relation to the earth-a passion which in turn presumes an ongoing dependence of the peasant on the land.

That women in the nineteenth century, and peasant women among them, could be identified through biology with both fertility and a cyclic nature, enabled gender to assert the peasant's presumed bonds to nature in a different way. Metaphors in nineteenth-century literature frequently equated the peasant woman with the fertility of the earth. As one example, a poem published in 1897, which described a female harvester returning from a day's labour, concluded: "Elle regagnera la toit familial/ Ayant dit sa prière à la glèbe profonde/ Comme elle maternelle, et comme elle féconde." ${ }^{11}$ However, more violent imagery could associate the body of the peasant woman with the earth that was to be owned and manipulated. Thus, Zola's La Terre of 1887 made numerous references to the peasant woman and the land as objects to be forcibly possessed in order to be made productive by the male. ${ }^{52}$ Griselda Pollock has noted, in discussing representations of peasant women within the realm of the visual arts, that one role of such imagery of fecundity and sexuality lay in defining norms of middleclass femininity:
The terms 'Woman' and 'Country' articulated through the female peasant were ideolologically bounded for the nineteenth-century bourgeoisie. The typically selective versions of the peasant woman as the young working mother or as a youthful and sexualised yet innocent adornment of abundant fields signifies within the bour- geois construction of femininity and masculine sexual- ity. Peasant women were not ladies, the embodiment of the feminine, but they were natural, pure and innocent, wholesome, procreative and domestic in contrast to the corrupt working women of the cities tarnished with the suspicion of immorality and prostitution because they worked for money. 53

Clearly, however, the cumulative effect of these representations was ultimately a conservatizing one. Whether intersecting with nineteenth-century definitions of masculinity or femininity, the myth of the peasant's bonds to, or identity with, the land produced an essentialist hierarchy, one wherein ie paysan-peasant men and peasant womencould be further differentiated from the modern urban dweller.

\section{The Painting}

That Salon critics in 1885 could read Breton's painting in relation to these dominating traditions was facilitated in part 
Figure 2. Gustave Jundt, L'Aurore, drawing by the artist after the painting exhibited in the Salon of 1882 (Photo: Charles de Morgues frères, Livret illustré du Salon [Paris, 1882], 203).

by Le Chant de l'alouette's own range of signs. Several aspects of the image of the peasant pausing in the fields at sunrise played upon the pervasive stereotype that assumed the peasant's ties to both nature and the land. In the context of rural genre within the French Salon, what Linda Nochlin has described as the "erotic charms" and "earthy sensuality" of Breton's youthful harvester ${ }^{54}$ provided a means to activate the numerous metaphors that worked to link peasant women with the cycles of the seasons and the day. Through the 1880 s visual representations that played upon such identities were a staple of Salon fare. Gustave Jundt's L'Aurore in 1882 (Fig. 2) juxtaposed the youth of a field worker carrying a sickle with the promise of a new day, while representations like Casimir Destrem's La Fin du jour in 1885 (Fig. 3) sentimentalized the rigours of agricultural labour through the spectacle of a setring sun. Arriculating the way in which gendered definitions circumscribed the female body in terms of the determining rhythms ascribed to nature, a particular set of such figurations worked to identify peasant women with the fertile cycles associated with the earth itself. ${ }^{55}$ François-Alfred Delobbe's Famille aux champs (Fig. 4), a painting in the Salon of 1881 , registers the characteristic juxtapositions. Seated in a harvest field as if a physical part of the year's growth, the young family of a peasant mother is displayed among the stubble of the wheat as the plenty of a productive harvest. Eugène Lejeune's Une Halte (Fig. 5) in the Salon of 1882 played upon a similar equation: a newborn infant is nursed by a young peasant woman atop a wheelbarrow filled with the harvest grain. A variant of this imagery was manipulated in Louis Prioux's Réveil du printemps of 1882 (Fig. 6), which features a peasant breast-feeding her child within a setting that evoked the spring regeneration of crops. ${ }^{56}$

In Le Chant de l'alouette the peasant's youth, in conjunction with European and Christian cultural traditions that linked the dawn with new life and the sickle with harvest plenitude, played on a related set of associations. Indeed, for viewers at the Salon of 1885 , this aspect of the painting's [Paris, 1885], 69).

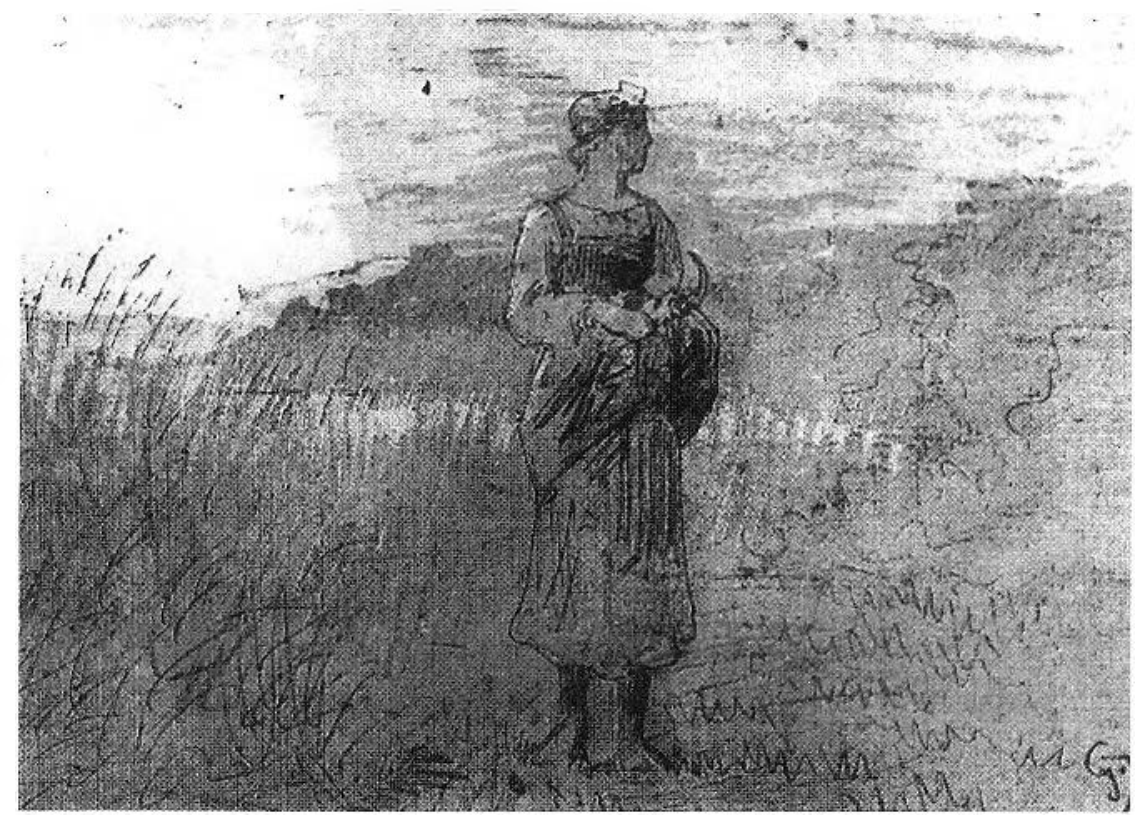

Figure 3. Casimir Destrem, La Fin du jour, Salon of 1885 (Photo: J. Noulens, Artistes français et étrangers au Salon de 1885

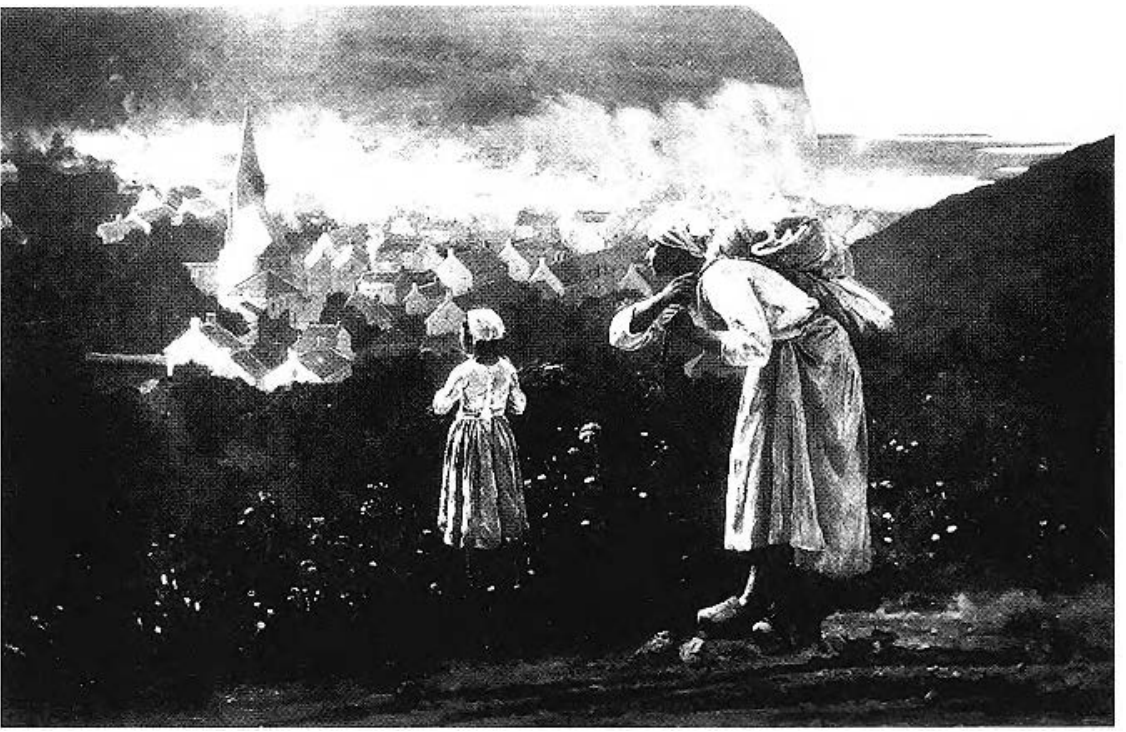

imagery was particularly reinforced by the exhibition of the work in proximity to another of Breton's representations of rural life; Le Dernier rayon (Fig. 7). In this latter painting, a rosy glow of sunset picks out an aged peasant couple as their grandchildren play in front of a thatched rural cottage. ${ }^{57}$ Sustaining this idyll and guaranteeing its future, the next generation of agricultural workers returns from the fields, marking the termination of another day's labour. Shown together, Le Chant de l'alouette and Le Dernier rayon could imply the continuum of a rural existence in which ongoing genera- 


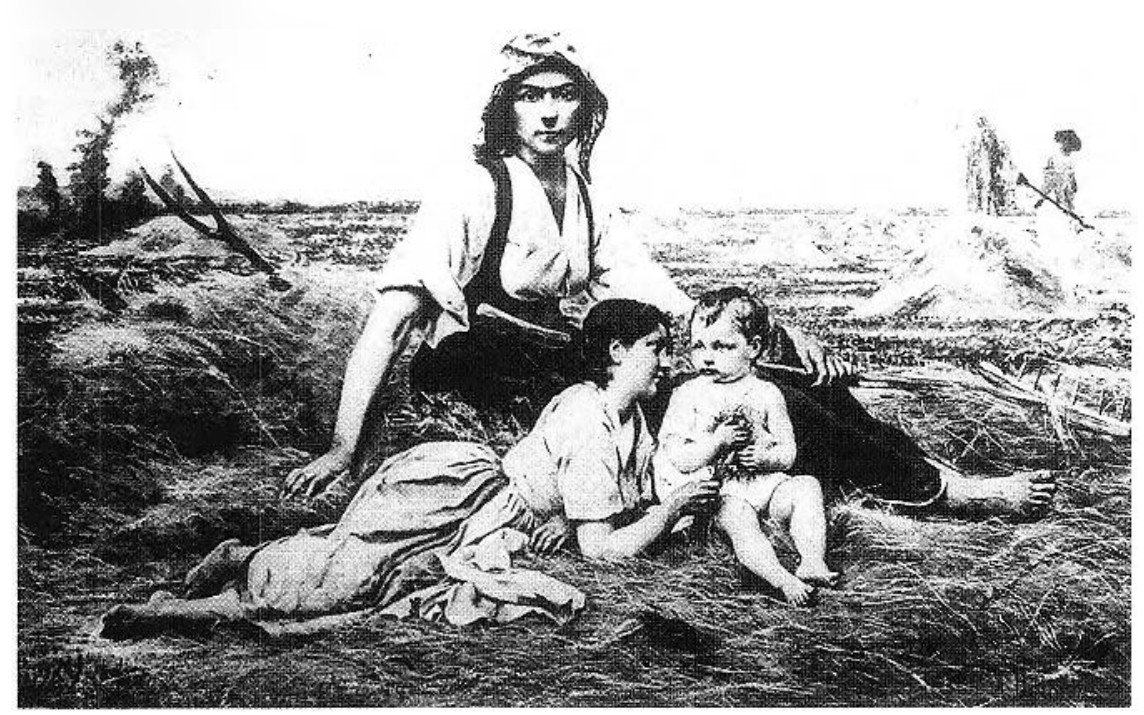

A central aspect of the painting's subject, the lark and its song, played an important role in reaffirming this image of rural stasis. Inhabiting open fields and passing the night in furrows and ditches, the lark was renowned for its song and its sudden flight skyward at the first signs of dawn. It was because of this response to the early morning light that ancient, Christian and popular folk culture associated the lark with qualities ranging from love of the divine to the poetically inspirational. While Greek writers equated the lark's song with a condition of innocence and prayer ${ }^{58}$ the Roman name for the lark, alauda, was associated with the Latin for "praise." "Christianity, working within these traditions, and with Lauds,

Figure 5. Eugene Lejeune, Une Halte, drawing after the painting exhibited in the Salon of 1882 (Photo: Charles de Morgues frères, Livret illustré du Salon [Paris, 1882]. 212).

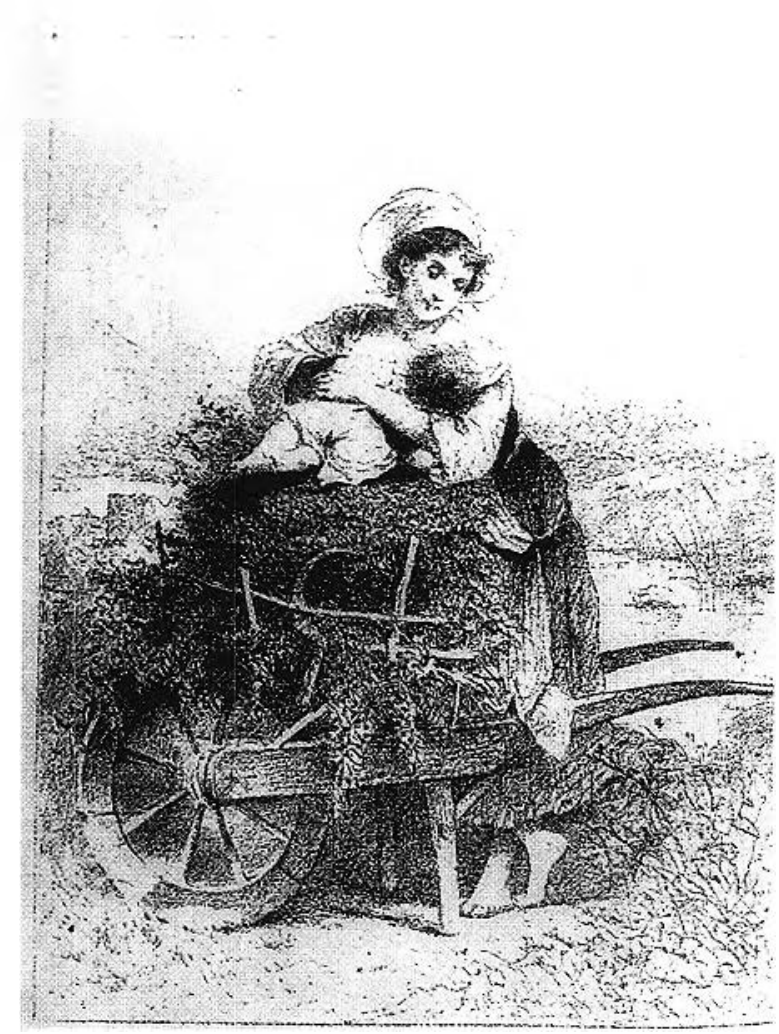

tions of rural labourers could be viewed as untouched by either technological change or the economic pull of industrial centres. Remaining attached to the fields, such a peasantry works - and procreates-in harmony with the natural world. the period of early morning prayer designed to end at dawn, ${ }^{60}$ transformed the lark into an emblem for praise of the divine. ${ }^{61}$ One result was that popular folklore in France saw the lark's sudden song at dawn as inspired by love of God. ${ }^{62}$ Gathering data on French rural culture at the end of the nineteenth century, folklorist Paul Sébillot observed that in some regions of the nation this equation was given expression in folk sayings which associated the lark's song with both the matin prayers and the lighting of the candles at morning mass. ${ }^{63}$ Sébillot also cited tales and folk-songs which described the lark as an intermediary between earth and heaven. ${ }^{64}$

In describing Le Chant de l'alouette in 1885, Salon critic Henri Chantavoine conjured up these well known associations of the lark with Christian worship when he described both the lark's and the peasant's song as a form of morning homage. ${ }^{65}$ However, the lark in nineteenth-century France carried another set of meanings that were also evoked in the painting's reception. That in Roman times the lark served as a crest designating the legion of warriors from Gaul, led nineteenth-century writers to stress that the bird had served as a form of national symbol for the Gauls as a whole. ${ }^{66}$ Indeed, this identification was given a special significance within oppositional and Republican histories of the nation. In 1856 the liberal historian Jules Michelet made current a polemical form of the various strands of lark lore.

Well known by 1850 as both an author of histories of France and as a supporter of the Republican opposition, Michelet was forced during the conservative Second Empire to give up his official lectureships because of his political affiliations. ${ }^{67}$ As a now necessary means of support, Michelet turned to the study of natural history, and his book 
Figure 6. Louis Prioux, Réveil du printemps, Salon of 1882 (Photo: Louis Enault, Paris Salon. 1882, 2 vols [Paris, 1882], I, "Prioux").

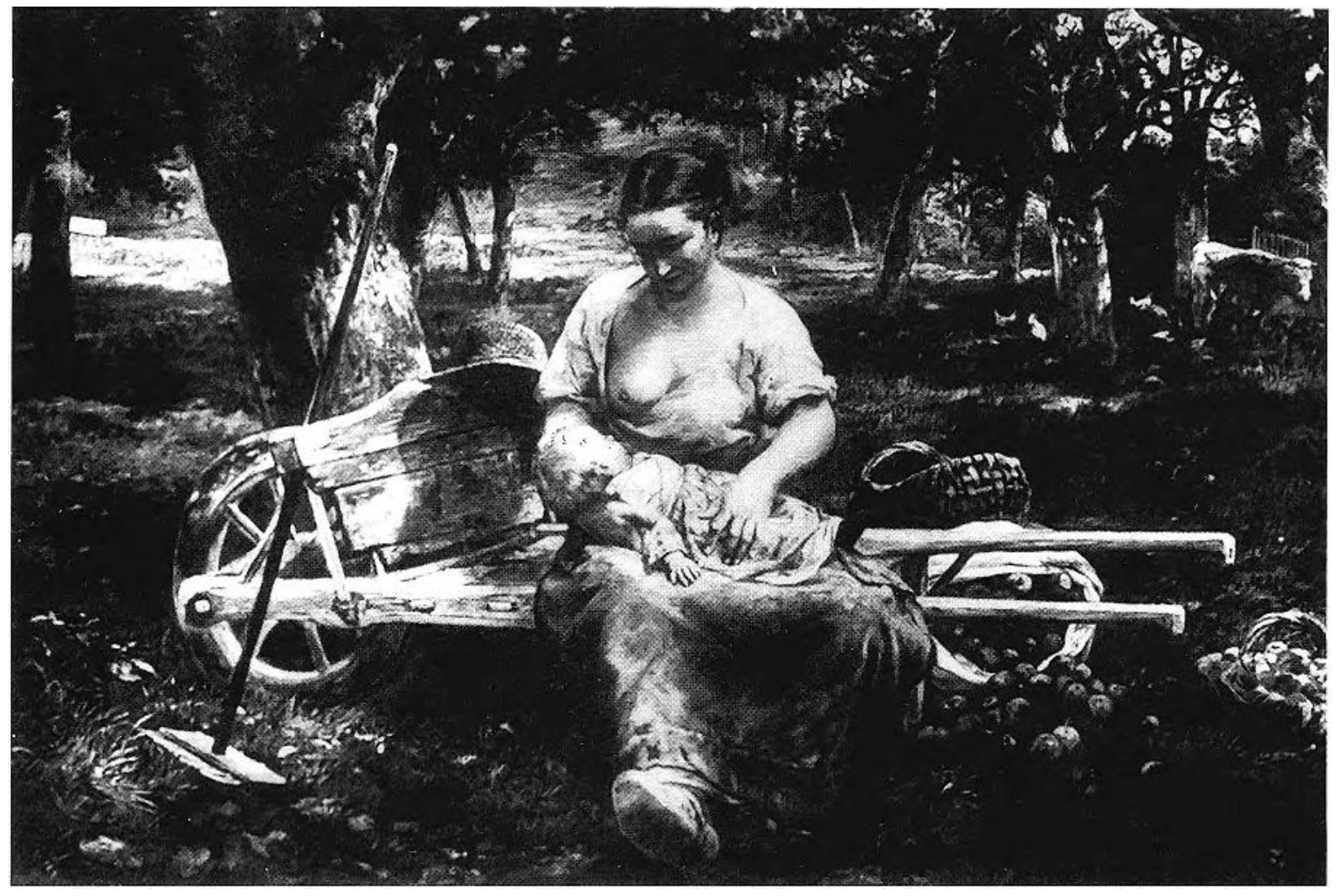

Figure. 7. Jules Breton, Le Dernier rayon, Salon of 1885 (Photo: J. Noulens, Arristes français et étrangers au Salon de 1885 [Paris, 1885], 35).

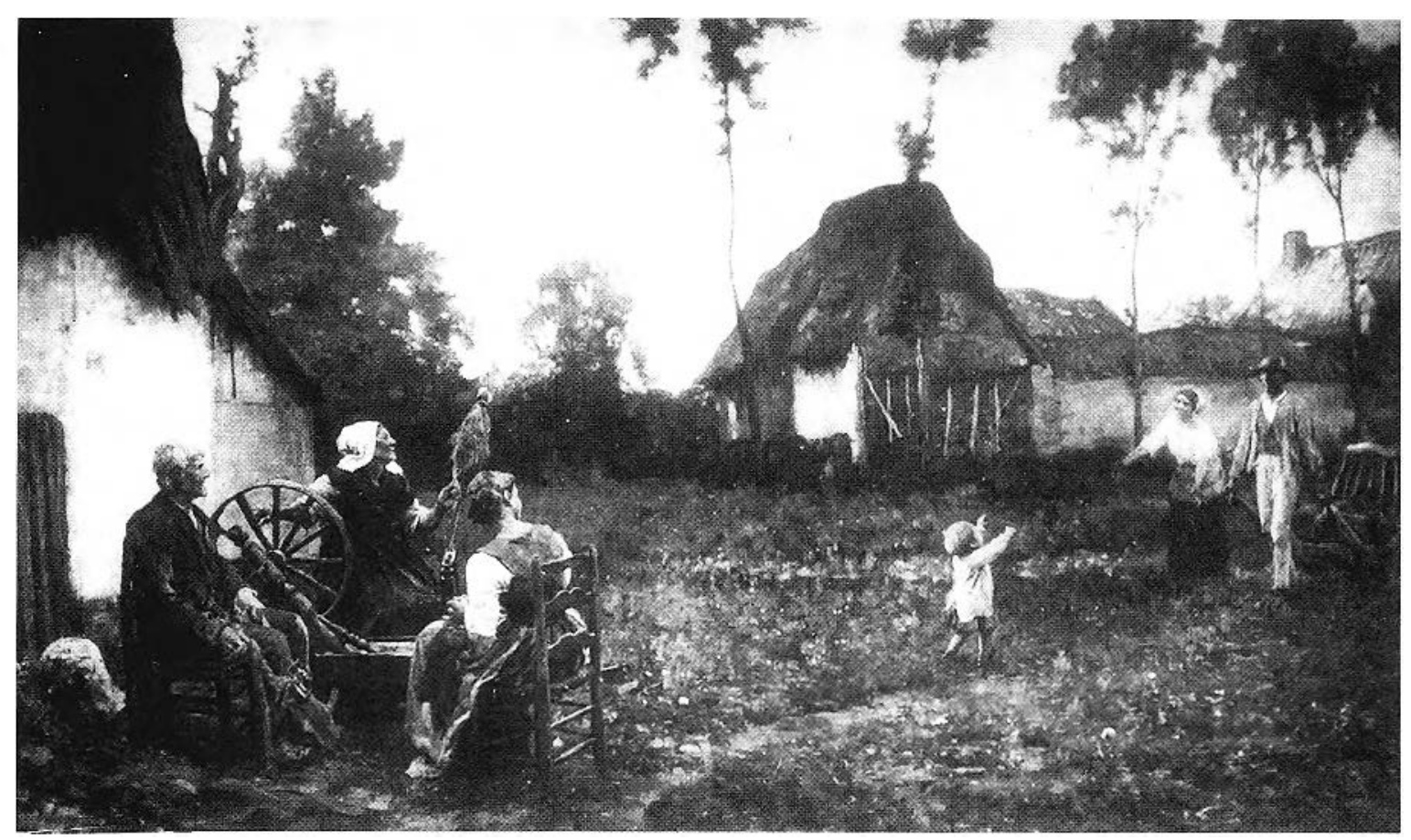


L'Oiseau was published in 1856. Significantly, this ostensibly non-political treatise on the birds of Europe was invested with some of the liberal ideology that had informed Michelet's earlier historical studies. The image in L'Oiseau of the lark as a symbol both of the peasant who laboured in the fields and of the spirit of hope, which Michelet saw as the quintessential characteristics both of ancient Gaul and modern France, stands as a case in point:

... l'oiseau de nos contrées, humble d'habit, riche de coeur, est près de pauvrc. Peu, très peu cherchent les beaux jardins, les allées aristocratiques, l'ombrage des grands parcs. Tous vivent avec le paysan .... L'oiseau des champs par excellence, l'oiscau du laboureur, c'est l'alouette, sa compagne assidue, qu'il retrouve partout dans son sillon pénible pour l'encourager, le sourcnir, lui chanter l'espérance. Espoir, c'est la vieille devise de nos Gaulois, et c'est pour cela qu'ils avaient pris comme oiseau national cct humble oiseau si pauvrement vêtu, mais si riche de coeur et de chant ... ${ }^{68}$

Continuing in a paragraph that specifically associated the lark with harvest workers, Michelet added:

C'est la fille du jour. Dès qu'il commence, quand l'horizon s'empourpre et que le soleil va paraître elle part du sillon comme une flèche, apporte au cicl l'hymne de joie .... Cetre voix sonore, puissante donne le signal aux moissonneurs .... Elle les suir, leur dit d'avoir courage. ... ${ }^{69}$

Michelet's evocative passages were in fact a reworking of a commentary on the lark published a year earlier in Le Monde des oiseaux by Alphonse Toussenel. There, Toussenel, a self-styled defender of Republican tenets (as well as a vocal anti-Semite), had pointed out the lark's association with ancient Gaul and in particular had made an overt equation berween the lark and the peasant labouring in the fields:

... la vie de l'Alouette est l'image fidèlc de cellc du laboureur. .. [sic] dont le travail est en possession de nourrir la paresse des oisifs depuis que le mondc est monde... . De même qu'il ne faut à l'Alouette qu'un rayon de soleil pour la rcmettre en joie, de même il ne faut au laboureur qu'une pluie qui tombe à propos pour lui rendre espoir et courage et le faire se rccourber avec une ardeur toute nouvelle sur la bĉche ou sur la charrue .... I'Alouetre vit donc de peu comme le cultivatcur et s'accommode de tout. Elle symbolise spécialement le serf attaché de la glèbe. Son ennemi lc plus terrible s'appelle le Hobereau, lc Gentillâtre, lc Boyard. Or l'abolition des privilèges de la féodalité tcrrienne cst le commencement de l'émancipation du travailleur, et l'Alouette aura sa nuit du 4 aôut comme les autres. ${ }^{70}$

Clearly, Michelet's formulation identifying the lark and the motto "hope" as Gaulish emblems, ${ }^{71}$ with both evoked as symbols of consolation for the modern French peasant at mid-century, was less politically explicit than that of Toussenel. The latter not only implied that the emancipation of the peasant had only begun with the French Revolution and the night of 4 August 1789 when the feudal system was abolished; he also called up privileges of land ownership in suggesting that the lark and the peasant had a set of shared enemies: wealthy landowners and nobility. Nevertheless, the accounts of both authors had an overt Republican cast which would not have been missed by readers in the first decade of the Second Empire. The references to Gaul were crucial here. Under the Bourbon and Orléanist monarchies, as well as under the Second Empire of Louis Napoleon, liberal and Republican historians self-consciously described Gaulish society as democratic in character and as a source for what was alleged to be an inherent love of liberty by the French. ${ }^{72}$ Defining Gaul in these terms was, a political ploy that served to counter conservative histories where the political organization of the forebears of the French nation was described in terms that echoed the hierarchic and authoritarian forms of modern monarchic and imperial rule. ${ }^{73}$ Locating liberty and democracy in France's earliest history, and implying the centrality of both to the evolution of "le peuple," thus provided a means to challenge the contemporary political and social order.

As has been noted, several critics reviewing the Salon of 1885 characterized Le Chant de l'alouette by linkithg the painting's imagery to the history of a Gaulish past. Charles Ponsonaille and Henry Fouquier pointed to the association of the lark with Gaul, while J. Noulens-also drawing on the association of the sickle with Druidic religious tradition as a sacred implement for the ritual harvest of mistletoe" - saw the peasant as a "druidess" and a "Celtic priestess." Théodore Véron described the harvester simply as "une Gauloise triomphante."

However, such readings at the time of the painting's Salon exhibition are not to suggest that in Le Chant de l'alouette Breton had deliberately formulated an image of the peasant with specific Republican references. Admittedly, in autobiographical comments published years later at the end of his career, Breton did underline his admiration for key Republican figures. There he described how he attended Michelet's lectures in 1848 and also emphasized his acquaintance with Léon Gambetta and Jules Ferry, leaders in the Republican government that came to power in 1879 
and prominent advocates of the liberal and laic politics of the new regime. ${ }^{76}$ Yet while youth, regeneration, the rising sun and even the peasant sowing in the fields were common devices used to refer to the early Third Republic and its claims to renewal, ${ }^{77}$ Le Chant de l'alouette at the Salon of 1885 escaped any identification with the parti pris of Republican politics.

Clearly an imagery that deployed tropes of the sexualized and fecund female body played a role here. However, this de-politicization of the lark and peasant association rested on other factors as well. By the mid-1880s, Michelet's identification of the lark, the peasant and Gaul had been divested of the radical or oppositional qualities that had informed its promotion in 1856 within the context of the Second Empire. One reason was that the Republican government, particularly following 1879 , had made concerted attempts to naturalize liberal histories through public mural and decorative programmes, official commissions of painting and sculpture and the implementation of new school curricula. ${ }^{78}$ Indeed, in an era when the new regime was eager to mark out its distance from any taint of radicalism, Micheler's moderate liberalism, with its own overt hostility to any left "Jacobinism" within Republican politics, played an important role in the government's efforts to distance itself from an appearance of left "extremism" and to forge a more conservative image. ${ }^{79}$ Of course, conservative factions through the early years of the Third Republic lamented the promocion of any ideology that upheld even the moderate liberalism of a "Girondist" politics. However, the right's own interest in these years in establishing the rural peasant as a bearer of traditional values, and as a source of strength and renewal for the nation, ${ }^{80}$ meant that conservative viewers at the Salon of 1885 could easily rally to a subject that linked the modern peasant to an unchanged rural past. Concurrently, attempts through the 1880s to forge a new nationalism by means of arguments that a nation's citizens were not defined by "race" or language but instead were bound by a shared cult of ancestors and a "glorious heritage," 81 also worked to subsume the image of the young harvester within a more general and less partisan context.

Breton's painting "style" with its idealized figural forms, harmonious colour gradations and restrained brushwork facilitated this effacement of any Republican associations that the conjunction of lark and peasant might have had in an earlier era. Associated with academic tradition, this pictorial means actively distanced itself from both the "official naturalism' promoted under the Third Republic and the avant-garde language of Impressionism, which carried its own associations with both political liberalism and a new democratization of vision. ${ }^{82}$ Thus when the Salon critic Henri Chantavoine referred to the lark and the peasant in Le Chant de l'alouette as "these two peasants"- "ces deux paysans" 83 - his phrasing suggests a familiarity with either Toussenel's or Michelet's passage on the lark where the parallel between the two was so evocatively made. The allusion, however, left out the implicit Republican critique of the peasant's political status which had originally been central to these authors' statements at mid-century. Other critics in 1885, and Jules Breton himself, seem to have effectively done the same.

Le Chant de l'alouette provided the possibility for several interdependent levels of reading for the Salon viewer in 1885 . The painting's imagery of the dawn, the peasant's youth and her association with the harvest could carry connotations of physical regeneration and fecundity which at once depended upon and reasserted stereotypes of bonds to the land and to nature. Linked to both Christian faith in the divine and the country's Gaulois heritage, the lark also offered ways of conjuring up a familiar set of associations that could affirm the persistence of the peasant as primitive, religious and tied to the traditions of the past, within the present of the modern nation of the 1880s.

\section{Conclusion}

Much of the visual vocabulary manipulated in Le Chant de l'alouette figured in imagery that had long been rehearsed by Jules Breton. Associations of the dawn with prayer and new life, the identity of the peasant woman with harvest fertility, and reference to the lark as an image of love and inspiration had been deployed in the artist's published verse and would be taken up again in Breton's own accounts of his youth in the countryside, published in 1890 and $1896 .{ }^{84}$ But the evocation of a static rural realm that bonds to nature and tradition could elicit-and, indeed, the identification of these with the body of the peasant woman - had other significances within the period. As theorist David Harvey has remarked, the recourse to constructs that assert tradition and the repetitive and predictable recurrences of cyclic time emerge particularly in periods when the shifts and dislocations of technological and industrial change mark their effects on the social fabric. ${ }^{85}$ Such was the case in France in the 1880s. Following 1879, Republican efforts to modernize the countryside through the creation of a laic and ostensibly democratic education program were much publicized as part of new liberal reforms. A major aim of Republican policy was to loosen the hold of the Catholic church on the rural population and to redirect the peasantry away from regional and local loyalties towards an iden- 
tification with the larger nation state. ${ }^{86}$ The reforms ultimately facilitated both economic and social change within the French peasantry; still, in the early years of the Republic they were the subject of heated public debate and were challenged repeatedly within the public sphere by conservative and Catholic factions. Indeed the Jules Breton who so eagerly vaunted his relationship with certain Republican luminaries in the 1890 s would register his own conservative sympathies in responding to the new government policies. In his autobiographical Un Peintre paysan published in 1896, the artist complained that the Republican programs which had given the peasant access to reading and writing skills had also resulted in the eradication of picturesque customs and the emergence of a modern dissoluteness. For Breton, the latter was clearly evidenced in what he considered as the loss of family unity and in the breakdown of the harmonic bonds between employer and worker that he saw as central features of the countryside in his own youth. ${ }^{87}$ In that past, he argued, an ordered world of class harmony had existed. Concern with individual rights on the part of the peasant had not yet replaced submission to so-called traditional virtues and duties, and science had not yet subverted belief in God. ${ }^{88}$

Although Breton's arguments were articulated some ten years following the first exhibition of Le Chant de l'alouette in the Paris Salon, the mythic countryside such comments evoke point to some of the issues at stake in this one genre painting's representation of the rural. Through an imagery that could link the young harvester to both the earth and seasons, as well as to Gaul and to religious tradition, Le Chant de l'alouette worked to naturalize an essentially conservative image of the peasant in 1885. As such, Breton's painting effectively located within the public arena of the Salon a visual counter to the social and political changes that were associated with the new Republican government. Indeed, the ability of the image to elicit a broad range of narrative associations played an important role here. Asserted through the work's construction by critics was a way of reading the world that challenged the empirical science and positivism specifically identified with the ideology of the new regime. ${ }^{89}$ Since 1879 , the pages of Salon reviews had addressed the threat that positivism was understood to pose to reigning theories of the human subject as able to act upon and interpret the world. ${ }^{90}$ Both Le Chant de l'alouette and its critical reception were positioned in relation to these issues by means of their claim that imagery and its referents served as parts of a larger signifying system and were not just components of a material order comprised of objectively verifiable data. Taken up as a result was a tenet central to the threatened ideology of academic high art in the nineteenth century: the notion of the artist as un poète-able by definition to divine and translate onto the canvas surface the interdependencies and hidden essentials alleged to lie beneath the surface of the physical world. ${ }^{91}$

Breton's rural idyll thus upheld the authority of tradition and the past on a number of levels. Yet, given the preceding analysis it is telling to compare Le Chant de l'alouette's reception in France with that in the United States following the work's purchase by Henry Field of Chicago in 1885, its exhibition at the Columbia Exposition in 1893, and its acquisition in 1917 by the Art Institute of Chicago. The painting was the object of much public admiration in its new locale; indeed, in 1934 it was voted the most popular painting in America in a nation-wide contest sponsored by a Chicago newspaper. ${ }^{92}$ An admittedly mediocre poem written by an American in 1898, and dedicated to Le Chant de l'alouette, suggests one factor which accounted for this popularity and which in turn gave the work a different character in its new context.

Dear maiden with uplifted face

And cyes in joyous reverence raised,

Far o'er the realms of song-thrilled space

Thy soul soars upward with the lark.

Thy rugged hand a sickle holds-

Death's symbol clasped by dawning life-

A rosy lighe thy form enfolds,

A new earthborn Aurora thou.

Thy spirit is not peasant born

Though night's pale dew clings round thy feet,

Forever on thee shines the morn

Srill in thy heart life's matin rings. ${ }^{93}$

While the verses do touch upon aspects of the painting's imagery which have been discussed in this study-the peasant's youth, her air of religious reverence and the play upon the dawn as an evocation of new life-it is readily evident that several of the stereotypes and connotations operative at the Salon of 1885 have no meaning here. Rather, it would seem that in the United States, where a peasantry and its associations with centuries-old traditions did not exist, the painting's allusions to renewal and awakening could appear as visual metaphors appropriate to the supposedly "classless" society of the new world, a society wherein individual aspiration and enterprise were to be the sole markers of success and the measures of individual worth. Thus in the eyes of one American at least, the young peasant's association with nature and her devotional aura identify her with new beginnings and hope, and it is these qualities in turn which 
serve to liberate and remove her from her peasant status. This interpretation provides a stark contrast to the range of stereotypes concerning la paysannerie in France in the second half of the nineteenth century. There, these same qualities were defining and circumscribing and ultimately served to assert that essential and unchanging ties bound the peasant to the land, to nature and to the early origins of the nation's past.

* This arcicle is derived in part from a chapter in my doctoral disscrtation "Peasant Paincing and its Criticism in France, 18751885: Themes and Debates," University of Chicago, 1987. Acknowledgement is gratefully made to the Social Sciences and Humanities Research Council of Canada for a doctoral fellowship which supported this research. I would also like to thank Reinhold Heller, University of Chicago, for initially suggesting that this topic was worthy of study, and Paul Matrick Jr. and Rhonda Esau for cncouraging me to revise an earlier formulation of my present argument.

1 See, for example: (.. Dareste de la Chavanne, Histoire des classes agricoles en France depuis Saint Louis jusquà I.ouis XVI (Paris, 1854); Eugène Bonnemère, Histoire des paysans depuis la fin $d u$ moyen age jusqu'à nos jours, 1200 - 1850. Précedée d'une introduction :an 50 avant J. C. - 1200, 2 vols (Paris, 1856); M.A. Leymarie, Histoire des paysans en France (Paris, 1856); and Henry Doniol, Histoire des classes rurales en France et de leurs progrès dans la l'égalité civile et la propriété (Paris, 1867).

2 Robert L. Herbert, "Millet Revisited," Burlington Magazine, CXIV (July 1962), 294-305; "Millet Reconsidered," Museum Studies, I (1966), 29-65; and "City vs. Country: The Rural Image in French Painting from Millet to Gauguin," Artforum, VIII (February 1970), 44-55; Linda Nochlin, Realism (Harmondsworch, 1971), 111-24; T. J. Clark, The Image of the People. Gustave Courbet and the 1848 Revolution (Princeton, 1982), especially, 150-53, and "Millet," in his The Absolute Bourgeois (Princeton, 1982), 72-98; Christopher Parsons and Neil McWilliam, "'Le Paysan de Paris': Alfred Sensicr and the Myrh of Rural France," The Oxford Art Journal, II (1983), 38-58; Fred Orton and Griselda Pollock, "Les données bretonnantes: la prairie de réprésentation," Art History, III, no. 3 (September 1980), 314-44; and Griselda Pollock, "Van Gogh and the Poor Slavcs: Images of Rural Labour as Modern Art," Art History, XI, no. 3 (Septcmber 1988), 406-32.

Other studies of the visual arts in this period that assess the mythology of rural life entertaincd by sectors of the nineteenthcentury French public include: Jean-Claude Chamboredon, "La Peinture des rapports sociaux et l'invention de l'éterncl paysan: les deux manières de Jean-François Millet," Actes de la recherche en sciences sociales, XVII/XVIII (1977), 6-28; Robert Bezucha, "Being Realistic about Realism: Art and the Social History of Nineteenth Century France," in The European Realist Tradition, ed. by Gabricl P. Weisberg (Bloomington, 1982), 1-13; and Michael Orwicz, "Criticism and Representation of Brittany in the Early Third Republic," Art Journal, XLVI (Winter 1987), 291-98.
3 For related studies on urban myths of the rural, see: Claude Grignon, "L'Enseignement agricole et la domination symbolique de la paysannerie," Actes de la recherche en sciences sociales, XI (1975), 87-90; Pierre Bourdieu, "Une classe objet," Actes de la recherche en sciences sociales, XVII/XVIII (1977), 2-5; Rémy Ponton, "Les images de la paysannerie dans le roman rural à la fin du 19e siècle," Actes de la recherche en sciences sociales, XVII/ XVIII (1977), 62-71; Catherine Bertho, "L'invention de la Bretagne, Genèse sociale d'un stéréotype," Actes de la recherche en sciences sociales, XXXV (1980), 45-62.

4 Purchased by Henry Field of Chicago in 1885, Le Chant de l'alouette was exhibited at the Columbia Exposition in 1893, and given to the Art Institute of Chicago in 1917. Hollister Sturges, ed., Jules Breton and the French Rural Tradition (Joslyn Art Museum, Omaha, 1982), 95, has pointed to the painting's popularity in the United States: Le Chant de l'alouette provided the title to Willa Cather's novel of 1915, The Song of the Lark; the painting was also voted the most popular in America in a poll run by a Chicago newspaper in 1934.

5 For surveys of Breton's life and career, see Marius Vachon, Jules Breton (Paris, 1899), and the essays of Hollister Sturges, Gabriel Weisberg, Annette Bourrut-Lacouture and Madeleine FidellBeaufort in Sturges, ed., Jules Breton and the French Rural Tradition. Breton also published poetry, a novel, studies on art and theory, and two autobiographical accounts. See Les Champs et la mer (Paris, 1875); Jeanne (Paris, 1880); Oeuvres poétiques (Paris, 1887); La Vie d'un artiste: art et nature (Paris, 1890); Un Peintre paysan: souvenirs et impressions (Paris, 1896); Savarette (Paris, 1897); Nos Peintres du siècle (Paris, 1899); La Peinture: les lois essentielles (Paris, 1904).

6 Concerning the representation of peasant women in rural subject matter of the second half of the nineteenth century, see Linda Nochlin, "The Realist Tradition," Burlington Magazine, CXXV, 963, (1983), 375-76; and Pollock, "Van Gogh and the Poor Slaves," 417.

7 The following offered particular praise for Breton's representation of the peasant: Henry Havard, "Le Salon," Le Siecle, 19 May 1885, 1; Henry Havard, Salon de 1885 (Paris, 1885), 44; J. Noulens, "I.e Salon de 1885," La Presse, 1 May 1885, 3; Charles Ponsonaille, "Le Salon de 1885," L'Artiste, I (1885), 347 48; Mario Prorh, "Voyage au pays des peintres," Le Réveil, 23 May 1885, 2; Roger Marx, "Le Salon de 1885," Le Voltaire, 1 May 1885, 1; Henri Chantavoine, "Le Salon de 1885," La Nouvelle revue, XXXIV (May-June 1885), 591-92.

8 André Michel, "Le Salon de 1885," Gazette des beaux-arts, ser. 2, XXXI (June 1885), 490.

9 Chancavoine, "Le Salon de 1885," 592-93.

10 Théodore Véron, Dictionnaire Véron (Paris, 1885), 88.

11 Ponsonaille, "Le Salon de 1885," 348.

12 Henry Fouquier, "Le Salon de 1885," Le Dix-neuvième siècle, 26 May 1885, 2.

13 J. Noulens, in "Le Salon de 1885," La Presse, 1 May 1885, 3; and in Artistes français et étrangers (Paris, 1885), 34. 
14 Claude-Gilbert Dubois, Celtes et Gauloises au XVI siècle: Le développement littéraire d'un mythe nationaliste (Paris, 1972), 21, 45.

15 The terms Gaulois and Celtes were often used intcrchangeably in the nineteenth century, as Gcorge Sand noted in her novel of peasant life, first published in 1844, Jeanne (Paris, 1852; repr., n.p., 1976), 77, n. 1. Henri Martin, Histoire de France depuis les temps les plus reculés jusqu'en 1789, 17 vols, 4th edn (Paris, 1878), I, 3-4 (who describes the Celts as a tribe within the confederation of Gauls), pointed to the confusion of Gauls and Celts in ancient Greek texts. The archaeologist Alexandre Bertrand in Les Gauloises. Lu à l'Académie des Inscriptions en avril 1875, Extrait de la Revue archéologique (Paris, 1875), 3-4, attempted to clarify the difference between the two terms. He discussed the tendency in the nineteenth century to treat the Gauls and Celts as one people and pointed out that the term Gaulois (Galli) was used by the Romans to signify scveral diverse tribes within Gaul at the time of the Roman invasion. Bertrand demonstrated (22) that the C.clts were an early tribc inhabiting ancient Gaul. Following the invasion by the Gaulois, the Celts migrated to occupy the centre and west of Gaul, with the Gaulois inhabiting the castern portion of the country.

16 Stanley Mellon, The Political Uses of History. A Study of Historians in the French Restoration (Stanford, 1958), 62; sce also 10, 13, and 62, for Mellon's observation that liberal historians following the French Revolution stressed the Gauls as a symbol of the nation in opposition to conservative histories which ignored le peuple and chronicled only the events of the Frankish monarchs. On the Frankish invasion and its significance to nationalism, see also Martin Thom, "Tribes within Nations: the Ancient Germans and the History of Modern France," Nation and Narration, ed. Homi K. Bhaba (London, 1990), 23-43.

17 For a survey of nineteenth-century interest in rural culture sce Hier pour demain: Arts, traditions et patrimonie, cxhibition catalogue, Paris, Grand Palais (Paris, 1980), and Madelcine FidellBeaufort, "Peasants Painters and Purchasers" in The Peasant in French 19th Century Art, exhibition catalogue, Dublin, Douglas Hyde Gallery (Dublin, 1980), 59-60. See also Charles Rearick, who in Beyond the Enlightenment. Historians and Folklore in Nineteenth Century France (Bloomington, 1974), 162-63, discusses briefly the Second Empirc's décret of 13 Scptcmber 1852 which authorized a Recueil des poésies populaires de la France. Political motivations for this statc interest in folklore studics are posed by Stanley Meltzoff, "The Revival of the Lc Nains," Art Bulletin, XXIV (September, 1942). 280; and Paul Vernois, Le Roman rustique de George Sand à Ramuz; ses tendances et son évolution (Paris, 1962), 42.

18 Dareste de la Chavanne, Histoire des classes agricoles, iii-vii; Bonnemère, Histoire des paysans, I, 1-4 ; Lcymarie, Histoire des paysans en France, 3-5. It should be noted that while these studies acknowledged the peasant's descent from the Gaulois, they took up different ideological stances on the significance of that descent. Dareste de la Chavanne and Leymaric praised the role of the church and monarchy in France's history and stressed the lib- erties of the peasant under the fcudal regime. Bonnemère, in contrast, characterized the peasant as oppressed and exploited ever since the Romans invaded Gaul, and liberated only by the reforms of the French Revolution. Although he did not commence with Gaul, like Dareste de la Chavanne and Leymarie, Doniol, in Histoire des classes rurales, defended the pre-revolutionary feudal order.

19 The phrase is from A. Cantaloube, "Salon de 1864," La Nouvelle Revue de Paris, 15 June 1864, 619, cited in Parsons and McWilliam, "'Lc Paysan de Paris': Alfred Sensier and the Myth of Rural France," 46; see also 40, note 8 and note 20.

20 Henri Martin, Histoire de France, 17 vols, 4th cdn (1833; Paris, 1878), I, 328.

21 Alexandre Bertrand, Nos origines: La religion des Gaulois: Les Druids et la Druidisme; leçons professés à l'école du Louvre, 1896 (Paris, 1897), 7. Bertrand explained (18), citing other scholars for support, that attempts by the church to purge the old Druidic beliefs, or at least to give them a cast more acceptable to Christianity, had not been successful, permitting the essential form and content of pagan traditions to survive into modern times. In support of his thesis, Bertrand citcd two nincteenth-century studics: $\mathrm{H}$. Gaidoz, "Rcligion des Gaulois," Encyclopédie des sciences religieuses, V (Paris, 1878), 429-41; and (in Nos origines, 22) E.rnest Renan's Nouvelles études d'histoire religeuse (Paris, 1884).

22 Sand, Jeanne, 190-91. Jeanne was originally published in I.e Constitutionnel, from 25 April to 2 June 1844.

23 Sand, Jeanne, "Norice," 2.

24 Sand, Jeanne, 13

25 Concerning ninctecnth-century urban views on the peasant and rcligion, see Orton and Pollock, "L.cs données brctonnantes," 332 36; and Bertho, "L'invention de la Bretagne," passim.

26 Amćdéc Thicrry, Histoire des Gaulois depuis les temps les plus reculés jusqu'à l'entière soumission de la Gaule à la domination romaine, 3 vols (Paris, 1828); and Martin, Histoire de France, I, 48-84. Rearick, Beyond the Enlightenment, $107 \mathrm{ff}$, discusses Martin's emphasis on 1)ruidic religion in the first edition of Histoire de France of 1833. Sec also Henri Baudrillart, Les Populations agricoles de la France, 2 vols (Paris, 1885; repr., Gencva, 1978),I: Normandie et Bretagne, passé et présent, 355-56.

27 Martin, Histoire de France, I, 1-2, 249-51, 328. Scc also Rearick, Beyond the Enlightenment, 108.

28 Ernest Renan, "I.a Poésic des races celtiques," Revue des deux mondes, ser. 2, V (January-March 1854), 497-98.

29 Bertho, "L'invention de la Brctagne," 45-62.

30 Rearick, Beyond the Enlightenment, passim; and Eugen Weber, Peasants into Frenchmen: The Modernization of Rural France, 18701914 (Stanford, 1976), 471-72. As a specific cxample, see Alexandre Bertrand, "I.es feux de la Saint-Jean," Magasin pittoresque, ser. 2, III (June 1885), 172-74.

31 Bertho, "Linvention de la Brctagnc," passim; Gabriel Wcisberg, "Vestiges of the Past: The Brittany Pardons of the Late Nineteenthcentury French Painters," Arts Magazine, LV (November 1980), 134. 
32 For conservative Catholic theorists such as Bonald, Joseph de Maistre, Frederic Le Play and La Tour du Pin, rural society was seen to provide a model in which the retention of religious traditions, attachment to property and unchanging moeurs recalled pre-revolutionary society, when social and moral bonds were alleged to be stable. On this subject see Irving Zeitlin, Ideology and the Development of Sociological Theory, 2nd edn (Englewood Cliffs, N.J., 1981), 48-60; and Mathew Elbow, French Corporative Theory, 1789-1948. A Chapter in the History of Ideas (New York, 1953), 44-48, on Bonald, de Maistre and Le Play, and 53-84, on La Tour du Pin and Le Play. See also Richard Griffiths, The Reactionary Revolution: The Catholic Revival in French Literature, 1870-1914 (London, 1966), 59-64, 261-73.

33 Gambetta's famous statement of 1877 , "le clericalisme, voilà l'ennemi," indicates the tenor of Republican concern over this issue; see Cent ans de vie français à "la Revue des deux mondes" (Paris, 1929), 510, and David Thomson, Democracy in France since 1870 (Oxford, 1964) 140.

34 Bonnemèrc, Histoire des paysans, II, 350-80, defines thc roles of le paysan propriétaire, le paysan fermier and le paysan prolétaire. Baudrillart, Les populations agricoles, I and II, passim, describes categories of agricultural labour according to region. See also Maurice Agulhon, Gabriel Désert and Robert Specklin, Apogée et crise de la civilisation paysanne, 1789-1914 (Paris, 1979), passim; Webcr, Peasants into Frenchmen, 115-30; and John Horne, "The Peasant in 19th Century France," in The Peasant in French 19th Century Art, 17-43.

35 The examples here are numerous. For the historian Jules Michclet, in Origines du droit français cherchées dans les symboles et formules $d u$ droit universel (Paris, 1837), xviii, the peasant was both married to the soil and linked to its productivity through the act of sexual possession. In Michclet's Le Peuple, cd. Lucien Refort (1846; Paris, 1946), 32, he presented the land as a mistress on whom the peasant gazes with love and who, in return, produces and is fruitful. André Theurier, in La Vie rustique (Paris, 1888), iii, described the peasant's supposed love for the land as instinctive; F. de WittGuizot, "Le paysan dans le roman contemporain," Le Correspondant, 10 August 1909, 533-34, used this construct of love for the land to provide the one unifying characteristic that linked an otherwise regionally diverse peasantry. Even the economic historian Michel Augé-Laribé, in L'Evolution agricole de la France (Paris, 1912), xi, quoted in Vernois, Le Roman rustique, 129-30, made use of this definition, arguing that mechanization and education had transformed the peasant of the ninereenth century-bound to the soil by love-into an artisan of the twentieth century-one who works the soil only as the practice of a learned craft. On the associated concept of the peasant's passion for the land, see Guy Robcrt, La Terre d'Emile 'Zola: étude historique et critique (Paris, 1952), 68-69, 85; Vernois, Le Roman rustique, 124 25; and Ponton,"Les images de la paysannerie," 66-67.

36 Leymarie, Histoire des paysans en France, 649.

37 Michelet, Le Peuple, 46-47. Théophile Gautier's famous response to Millet's Le Semeur of 1852, to the effect that the peasant in the painting seemed to be rendered with the very earth he was sow- ing, used the art critic's language of colour and paint to conjure up these same inextricable bonds scen as linking the peasant to the land. Gautier's Salon review is quored (unfortunately withour reference to source or date) in Etienne Moreau-Nelaton, Millet raconté par lui-même, 3 vols (Paris, 1921), I, 87. The similarity between Gautier's and Michelet's imagery has been pointed out in Nochlin, Realism, 115.

38 See, for example, Hippolyte Taine, "Preface," Essais de critique et d'histoire, 2nd edn (Paris, 1866), quoted in Hippolyce Taine, Philosophie de l'art; Voyage en Italie. Essais de critique et d'histoire, ed. Jean-François Revel (Paris, 1964), 191. Such theories were drawn in part from the naturalist studies of Cuvier and St. Hilaire.

39 Michelet, Le Peuple, 149.

40 Renan, "La poésie des races celtiques," 473-76.

41 Sand, Jeanne, 67.

42 See, for cxample H. Léo, "Le Salon," Le Correspondant, VII (1883), 550. Ernest Duvergier de Hauranne, "Le Salon de 1872," Revue des deux mondes, ser. 2, XCIX (5 June 1872), 837, commented in response to viewing Jules Breton's Jeune fille gardant des vaches, that the monotonous labours and apparently vegetative existence of the peasant had their effects: "Cette âme à moitié endormic s'éveille parfois sourdement; elle s'écoute vivre, mais elle ne cherche pas à s'cnvoler de terre; elle reste comme ces bonnes vaches, attaché au sol qui la nourrit."

43 George Sand, La Mare au diable (1846; Paris, 1964), 39.

44 Sand, La Mare au diable, 33-35.

45 Bonnemère, Histoire des paysans, II, 410-11.

46 Ernest Chesneau, "J.F. Millet," Peintres et statuaires romantiques (Paris, 1880), 310-11. Chesneau's formulation, which first appeared in the Gazette des beaux-arts, ser. 2, XI (May 1875), 30123, and which can be dated to 11 May of that year, paraphrases closely that of Sand in La Mare au diable, 39, where she discusses the ability of the urban visitor to the countryside to take in "l'harmonie des couleurs et des sons, la finesse des tons et la grâce des contours, en un mor la beauté des choses."

47 Louis de Fourcaud, "Le Salon," Le Gaulois, 11 May 1882, 1. André Theuriet's La Vie rustique (Paris, 1888), 111 , also pointed out the peasant's seeming imperviousness to the "poésie" of the environment. Not surprisingly, medical and scientific discourses reinforced such analyses. See, for example, Dr. Amedée Chassagne, "L'Ethnographie de la Basse Bretagne," Revue d'anthropologie, IV (1881), 439-47.

48 Concerning these oppositions, see Tamar Garb, "Renoir and the Nacural Woman," Oxford Art Journal, VIII, no. 2 (1985), 7-14; and Thomas I.aqueur, "Orgasm, Generation and the Politics of Reproductive Biology," The Making of the Modern Body: Sexuality and Society in the Nineteenth Century, ed. Catherine Gallagher and Thomas Laqueur (Berkeley, 1987), 1-41.

49 Michelet, Le Peuple, 32; Bonnemère, Histoire des paysans, I, 66.

50 L'Intermédiare des chercheurs et curieux, XVIII, no. 410 (10 June 1885), column 321: "Chez les tragique grecs le verbe . . labourer, s'emploie pour représenter l'acte conjugal." Excerpes from Sophocles, Lucretius and Virgil are quoted as examples; 
L'Intermédiare, XVIII, 411 (25 June 1885), column 375, provides a related example from Rabelais' Pantagruel; L'Intermédiare, XVIII, 412 (10 July 1885), column 401, cites Erasmus and Rabelais; L'Intermédiare, XVIII, 417 (25 September 1885), column 553, quotes Montaigne. See also L'Intermédiare, XVIII, 414 (10 August 1885), column 462 .

51 Hector-Michel Bonnenfant, "La Moissoneuse," in Anthologie des instituteurs-poets, ed. M. Besson and M. Abadie (Paris, 1897), quoted in Françine Muel, "Les instituteurs, les paysans et l'ordre républicaine," Actes de la recherche en sciences sociales, XVII/XVIII (1977), 58. It is worth noting that ethnographic historian Martine Segalen has pointed out that such equations between women and the land or its agriculcural products were operative in nineteenthcentury peasant culture itself. There, women's fertility (or lack of it) could be evoked through comparison to a range of seasonal growth: flowers in bloom or gone to seed, or vegetables at their peak or withered and past their prime. See Martine Segalen, "Le marriage, l'amour et les femmes dans les proverbes français." Ethnologie francais, V, (1975), 123. Concerning the general western tradition which has equated women, landscape and nature, see Gillian Rose, Feminism and Geography: The Limits of Geographical Knowledge (Minneapolis, 1993), 93-99.

52 See Robert, La Terre d'Emile Zola, 311, and Emile Zola, La Terre (Paris, 1970), 102, 123, 418-28, where the rape of the peasant Françoise is equated with desire for land.

53 Pollock, "Van Gogh and the Poor Slaves," 417.

54 Linda Nochlin, "Women, Art and Power," in Visual Theory: Painting and Interpretation (New York, 1991), 30.

55 See also the discussions by Nochlin, "Women, Art and Power," 30, and Pollock, "Van Gogh and the The Poor Slaves," 416-417."

56 Jundr's L'Aurore, photo source: Charles de Morgues frères, Livret illustré du Salon (Paris, 1882), 203; Delobbc's La Famille aux champs, photo source: Louis Enault, Paris Salon, 1881 (Paris, 1881), facing 99. Lejeune's Une Halte, photo source: Charles de Morgues frères, Livret illustré du Salon, 212. Prioux's Réveil du printemps, photo source: Louis Enault, Paris Salon. 1882, 2 vols. (Paris, 1882), 1: "Prioux."

Similar equations between peasant fertility and that of the earth were made by other artists in France and Europe as a whole during the second half of the nineteenth century. See Linda Nochlin, "Léon Frédéric and the 'Stages of a Worker's Life'," Arts Magazine, LV (December 1980), 141, for Segantini's Two Mothers, 1888. and 142 for both Mackensen's Nursing Peasant, 1892, and Patini's Mattock and Milk, 1883.

57 A poem by Breton accompanied the entry for the painting in the Salon Livret, see Chantavoine, "Le Salon de 1885," 592).

58 Angelo de Gubernatis, Zoological Mythology, or the Legends of the Animals, 2 vols (London, 1872), II, 273-74, notes that Aristophanes stated that the lark existed bcfore Earth, that Goropious claimed that the lark sang seven times a day as a prayer to God, and that prayer existed before all other things.

59 Alphonse Toussenel, L'Esprit des bêtes. Le Monde des oiseaux. Ornithologie passionelle, 3 vols (Paris, 1855-59), II (1855), 166, pointed out: "On a fait dériver le nom alouette, en latin, Alauda, des deux mots à laude, de la louange comme qui dirait l'oiseau chargé de chanter les louanges du Seigncur." Pierre Larousse's Le Grand dictionnaire universel du dix-neuvieme siècle, 15 vols (Paris, 1866), I, 229, s.v. "Alouette," is also sceptical about this etymology: "Ce petit oiseau, disait-on, est dans l'usage de s'élever vers le ciel sept fois le jour en chantant les louanges du Créateur; et c'est pour cette raison que, suivant les etymologistes de fantaisie, il a reçu son nom d'alouetre, alauda, des dcux mots à laude." Beryl Rowland, Birds with Human Souls, A Guide to Bird Symbolism (Knoxville, 1978), 97, has noted that according to modern erymology alauda was not derived from the Latin for "praise" but was a borrowing of the Celtic name for the bird formed from, al (high) and aud (song).

60 Pierre Larousse, La Grande encyclopédie. Inventaire raisonné des sciences, des lettres, et des arts, 31 vols (Paris, 1894), XX, 48.

61 de Gubernatis, Zoological Mythology, II, 275, n. 1.

62 Rev. Charles Swainson, The Folklore and Provincial Names of British Birds (London, 1886), 94, reported that for the French peasant, "the lark in her upward flight pours forth prayers to God, beseeching him to allow her to soar to the sky. . . ." In Tourainc, he added, the lark's song was considered as a plea to St. Peter to be allowed into heaven.

63 Paul Sćbillor, Le Folklore de France, 3 vols (Paris, 1906), III, 184 85.

64 Sébillor, Le Folklore de France, III, 184-86, 209.

65 See note 9 above. The critic André Michel also saw the image as having a quasi-religious quality.

66 Toussenel, Le Monde des oiseaux, II, 170, called the lark "une des gloires nationales de la France" and cited Michelet's study of Julius Caesar for having evocatively discussed "cet emblème tout national," in the context of the Gaulois legion formed under Caesar and called "Alouettes." Larousse, Le Grand dictionnaire, I, 229, s.v. "Alouette," also noted that the Gaulois considered the lark as a sort of national symbol, and discussed the Gaulois legion of "Aloucttes." For the Roman sources concerning this Gaulois legion, see de Gubernatis, Zoological Mythology, II, 275, and Amedéc Thierry, Histoire des Gaulois, 2 vols, 8th edn (Paris, 1870), II, 354.

67 John P. MacKay, "Introduction" in Jules Michelet, The People (Urbana, 1973), xxiii.

68 Jules Michelet, L'Oiseau (Paris, n.d.), 220-21.

69 Michclct, L'Oiseau, 222.

70 Toussenel, Le Monde des oiseaux, II, 172-73.

71 Michclct's attribution of Espoir, "hope," as a motto of the Gaulois perhaps derives from the coins believed to be of Gaulish origin which were struck with the Latin for hope, "Spes." See Bonnemère, Histoire des paysans, I, 25.

72 Mellon, The Political Uses of History, 9-11, 62 on Carrion-Nisas, Augustin Thierry and Guizor; Rearick, Beyond the Enlightenment, 110-11, on Martin. See also Larousse, Le Grand dictionnaire, VIII, 1081 , s.v. "Gauloise:" "Remonte à nos premicrs siècles et vous 
trouverez une confédération Gauloise et point du roi." On Larousse's Republicanism, see Maurice Agulhon, Marianne au combat: L'Imagerie et la symbolique républicaine de 1789 à 1880 (Paris, 1979), 44.

73 On conservative histories see Mellon, The Political Uses of History, 15, 62-63, 69.

74 Martin, Histoire de France, I, 69-70; Thierry, Histoire des Gaulois, I, 492.

75 Sec notes 10,11, 12, and 13 above.

76 For Micheler, see Jules Brcton, The Life of an Artist, transl. by Mary J. Serano (New York, 1892), 177; for Gambetta see ibid., 275; for Gambetta and Ferry, see Brcton, Nos peintres du siècle, 85.

77 Youth, spring and the concept of regeneration were mctaphors used to represent the Third Republic in its early years. See, for example, H. Lucas' painting exhibited in the Salon of 1885 , Printemps sacré (illustrated in Havard, Salon de 1885, facing 7), which made use of spring and new growth imagery to refer to the nation. Popular illustrations particularly made use of such metaphors for renewal. See, for examplc, Gilbert Martin, Le Bon grain, published in Le Don Quichotte, 21 April 1882, and illustrated in Paul Ducatel, Histoire de la Troisième République. Vue à travers l'imagerie populaire et la presse satirique, 5 vols (Paris, 1973-79), II: Naissance de la République, 127. Here, a peasant sows the new seed of the future under thc auspices of the rising sun of the new Republic. For the sun and light as symbols of Republicanism, see Jean-Paul Bouillon, "'A Gauche!' Nore sur la Société du Jing-Lar et sa signification," Gazette des beaux-arts, ser. 6, XCI (March 1978), 107-18, and Agulhon, Marianne au combat, 26, 60.

78 For the inculcation of Republican values in the texts of the new laic schools, see Pierre Nora, "Ernest Lavisse: son rôle dans la formation du sentiment national," Revuc historique, CCXXVIII (JulySeptember 1962), 73-106; Louis Trenard, "Préface," in Bernard Ménager, La Laïcisation des écoles communales dans le département du Nord, 1879-1899 (Lille, 1977), non-paginated; Ponton, "Les images de la paysanneric," 65, n. 11; Webcr. Peasants into Frenchmen, 331-36; Alain Mougniotte, Les Dibuts de l'instruction civique en France (Lyons, 1991); and Jules Steeg, Morale et civique. L'homme et le citoyen à l'usage de l'enseignement primaire, ouvrage rédigé conformément au programme officiel (Paris, 1882). For state encouragement of subjects which celebrated events in French history that illustrated the ideals of the new Third Rcpublic, see Jules Ferry, Minister of Public Instruction and of Fine Arts, speech of 27 July 1879 , reprinted in the Journal officiel, 28 July 1879 . The relevant parts of this spcech arc paraphrased in Eugène Loudon. "Lc Salon de 1880," Revue du monde catholique, VII (1880), 454.

79 See Alice Gérard, La Révolution française; mythes et interprétations, 1789-1970 (Paris, 1977), 69, n. 2, for Micheler's status in this era. From 1871 on, comparisons between the government of the Third Republic and either the radical Jacobin or more moderate Girondin factions of the Revolutionary era were frequent. See Gérard, La Révolution française, 58, 72; and Paul Farmer, France Reviews her Revolutionary Origins: Social Politics and Historical Opinion in the Third Republic (New York, 1944), 38-50.
80 See note 3 above. For Breton's subscription to this theme, see his Un Peintre paysan, 84-85.

81 See Ernest Renan "What is a Nation," lecture delivered at the Sorbonne, 11 March 1882; translated by Martin Thom in Homi K. Bhaba, ed., Nation and Narration (London, 1990), 19. See also the discussion by Martin Thom, "Tribes within Nations," in Bhaba, ed., Nation and Narration, 31-35.

82 Concerning the Third Republic and the promotion of naturalism, see Michael R. Orowicz, "Anti-academicism and State Power in the Early Third Republic," Art History, XIV (December 1991), 571-92. On the association made between the avant-garde and liberalism in the early years of the Republic, see Stephen F. Eisenman, "The Intransigent Artist or How the Impressionists got their Name," in The New Painting; Impressionism 1874-1886, Washington D.C., National Gallery of Art (Washington, 1986), 51-59.

83 See note 9 above.

84 See, as examples, Breton's poem Aurore of 1875 in his Oeuvres poétiques, 19, which links the dawn with youth, awakening and love, and his epic poem Jeanne (1880) in Oeuvres poétiques, 12123. In Un Peintre paysan of 1896,99 , Breton associates an imagery of dawn with prayer. For Breton's use of stereotypes concerning the peasant's "innate" religiosity, of a healthful identity with harvest regeneration, and of an alleged maintenance of age-old traditions, see his Un Peintre paysan, 10-100; also his La Vie d'un artiste, of 1890, 1-80.

85 David Harvey, The Condition of Postmodernity: An Inquiry into the Origins of Cultural Change (Oxford, 1989), 201-02.

86 Mona Ozouf, L'Ecole, l'église et la république, 1871-1914 (Paris, 1963), passim; Weber, Peasants into Frenchmen, 332-38; and Trenard, "Preface," in Ménager, La Laicisation des écoles, non-paginated.

87 Breton, Un Peintre paysan, 45-46, 95-96.

88 Breton, Un Peintre paysan, 45-46, 84, 95-96.

89 On the Third Republic and positivism, see Louis Legrand, L'Influence du positivisme dans l'oeuvre scolaire de Jules Ferry. Les Origines de la laïcité (Paris, 1961), cited in Trenard, "Préface" to Ménager, La Laïcisation des écoles, non-paginated; Sanford Elwitt, The Making of the Third Republic: Class and Politics in France, 1868-1884 (Baton Rouge, 1975), 172-78.

90 This subject is discussed in my unpublished Ph.D. dissertation, "Peasant Painting and its Criticism in France 1875-1885: Themes and Debates," University of Chicago, 1987, 175-95.

91 Articulated most clearly in Charles Blanc, Grammaire des arts du dessin, architecture, sculpture et peinture (Paris, 1867), passim. These theories were reiterated by conservative Salon critics throughout the 1870 s and 1880 s and are addressed by Jules Breton himself in Nos Peintres du siècle, passim.

92 Sturges, ed., Jules Breton and the French Rural Tradition, 95.

93 Avilda Kilton Lee, "The Song of the Lark," Brush and Pencil, III (1898), 287. 